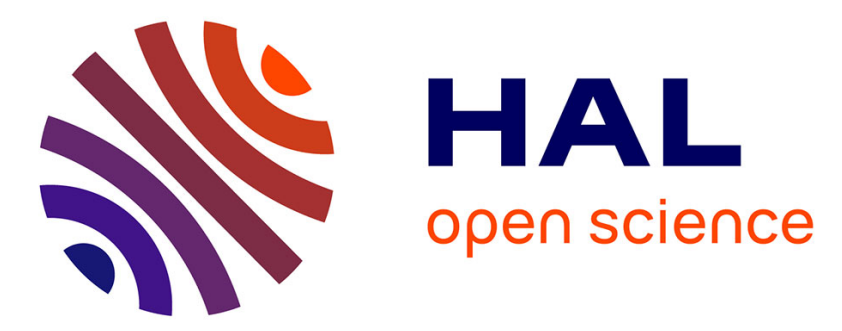

\title{
Hydrogeological model of a high energy geothermal field (Bouillante area, Guadeloupe, French West Indies)
}

\author{
Patrick Lachassagne, Jean-Christophe Maréchal, Bernard Sanjuan
}

\section{To cite this version:}

Patrick Lachassagne, Jean-Christophe Maréchal, Bernard Sanjuan. Hydrogeological model of a high energy geothermal field (Bouillante area, Guadeloupe, French West Indies). Hydrogeology Journal, 2009, 17 (7), pp.1589-1606. 10.1007/s10040-009-0486-3 . hal-00462254

\section{HAL Id: hal-00462254 \\ https://hal.science/hal-00462254}

Submitted on 25 Mar 2010

HAL is a multi-disciplinary open access archive for the deposit and dissemination of scientific research documents, whether they are published or not. The documents may come from teaching and research institutions in France or abroad, or from public or private research centers.
L'archive ouverte pluridisciplinaire HAL, est destinée au dépôt et à la diffusion de documents scientifiques de niveau recherche, publiés ou non, émanant des établissements d'enseignement et de recherche français ou étrangers, des laboratoires publics ou privés. 


\title{
Hydrogeological model of a high energy geothermal field (Bouillante area, Guadeloupe, French West Indies)
}

\author{
P. Lachassagne ${ }^{1 * \otimes}$, J.C. Maréchal ${ }^{2}$ and B. Sanjuan ${ }^{3}$
}

1. BRGM, Water Division, Hard Rock Aquifers Unit, 1039, rue de Pinville, 34000 Montpellier, France. Fax : 33-4 671579 75, p.lachassagne@brgm.fr, $\square$ corresponding author

2. BRGM, Water Division, Hard Rock Aquifers Unit, 1039, rue de Pinville, 34000 Montpellier, France

3. BRGM, Department of Geothermal Energy 3, Av. Claude Guillemin - 45060 Orléans Cedex 2, France

\begin{abstract}
The Bouillante geothermal field presently provides about $8 \%$ of the annual electricity needs of the French West Indies island of Guadeloupe. It has been the subject of a large number of studies covering various disciplines. These results enable the proposal of a hydrogeological conceptual model of the field. The reservoir consists of two perpendicular sets of fractures and faults, related to major regional tectonic structures. The capacitive and transmissive functions of the field are assured by these deep faults and fractures, which have been clogged near surface by self sealing and clay fill phenomena. The heat exchanges of the reservoir with the outside are thus reduced, through thermal and moreover hydraulic blanketing, to conductive transfers. Convection cells are active within the reservoir, ensuring its thermal and geochemical homogeneity. Heat exchange with the magmatic chamber is only conductive. The $\mathrm{Na}-\mathrm{Cl}$ geothermal fluid in the reservoir is composed of about $60 \%$ sea water and $40 \%$ fresh water of meteoric origin and has reached a chemical equilibrium with a mineralogical assemblage at $250-260^{\circ} \mathrm{C}$. This equilibrium state, the absence of tritium in solution, the low ratio between water in and out fluxes and the large reservoir volume (estimated at more than 30 millions $\mathrm{m}^{3}$ using tracer tests) suggest a relatively long ( $>100$ years) residence time of the geothermal fluid in the reservoir. Three main factors, all essential, explain the existence and location of the Bouillante geothermal field: a heat source (cooling hypovolcanic intrusion), a network of permeable fractures at the origin of the geothermal aquifer, and an impermeable surface cover, limiting the loss of energy and ensuring the durability of the field.
\end{abstract}

Keywords: Bouillante, faults, geology, geothermal field, geothermometry, groundwater, Guadeloupe, hydrodynamics, hydrogeochemistry, thermometry, volcanism, thermal springs

\section{Introduction}

The Bouillante geothermal field is located on the volcanic island of Basse Terre that, together with the adjoining island of Grande Terre, forms Guadeloupe. Both islands are part of the French West Indies (Figure 1) that lie on the Lesser Antilles island arc (Andreieff, Bouysse et al. 1989). The site is located on the west coast of Basse Terre Island, half way between the north and south ends of the island (Figure 2). With a water temperature of about $260^{\circ} \mathrm{C}$, no vapor in the aquifer and an enthalpy of about $1100 \mathrm{~kJ} / \mathrm{kg}$, the Bouillante geothermal field is

\footnotetext{
Corresponding author
} 
considered as a high energy, high temperature, medium to low enthalpy geothermal field (Zarrouk et al., 2006).

This area has been long known for its terrestrial hydrothermal surface expressions (hot springs, mud pools, steaming grounds and fumaroles) and consequently the village has been named 'Bouillante' which means 'boiling' or 'off the boil' in French.

The development of the Bouillante geothermal field follows several key periods which will be presented in the chapter 2 of this paper. Today, the Bouillante power plant is constituted of two units (GB1 and GB2), with a total installed power output close to $15 \mathrm{MWe}$ that are supplied by three geothermal wells (BO-4, BO-5 and BO-6). It covers about $8 \%$ of the annual electricity consumption of Guadeloupe (450,000 inhabitants). The plant contributes significantly to a secure electricity supply of the island as well as to a decrease in its production cost (in Guadeloupe most non geothermal electricity is generated by burning fossil fuels), and to a concomitant reduction in greenhouse gas emissions.

Multidisciplinary data acquired on the Bouillante site over the past years, cover geology, geophysics, hydrodynamics, hydrogeochemistry, geothermometry, etc., and range from the regional scale of Guadeloupe to that of a well or an outcrop. Combining and crosscorrelating these various data has led to significant progress in the understanding of the geothermal field and to proposing a complete hydrogeological conceptual model that is described in this paper. As, in geothermics, most of (natural or man induced) heat transfers rely on water fluxes (either liquid or vapour), this model is largely oriented towards the hydrodynamics of this area.

Such a hydrogeological model is indispensable from an operational viewpoint, in particular in view of ongoing projects on site. These include increasing the actual power production through development projects for the geothermal field (feasibility studies for a third stage started in 2004), and production improvements such as a reinjection project. Such a model also is the first stage of mathematical modelling of the field.

Several conceptual models of high energy geothermal fields have been published (see for instance (Westercamp and Traineau 1987; Akasako, Matsuda et al. 2002; Arellano, Garcia et al. 2003; Batini, Brogi et al. 2003; Tamanyu and Wood 2003; Bertini, Casini et al. 2006; Dilsiz 2006) for a context of andesitic type volcanism (or for shallow granitic intrusions), or (Bodvarsson, Benson et al. 1984; Bodvarsson, Pruess et al. 1984a; Bodvarsson, Pruess et al. 1984b; Gandino, Guidi et al. 1985; Ingebritsen and Scholl 1993; Violette, Ledoux et al. 1997; Hulen and Anderson 1998) for basaltic type volcanism.

Most of these conceptual models present, with varying degrees of precision and exclusively in 2D (cross section), the geological and geophysical structure of the subsurface. Some also identify the source of deep heat, in general a magma chamber (Bodvarsson, Benson et al. 1984; Bodvarsson, Pruess et al. 1984a; Bodvarsson, Pruess et al. 1984b) or an intrusion (Batini, Brogi et al. 2003; Tamanyu and Wood 2003; Bertini, Casini et al. 2006). The modes of heat transfer to the surface remain generally imprecise. The respective roles of different types of 'fluid' (water, gas, steam) (Akasako, Matsuda et al. 2002; Arellano, Garcia et al. 2003; Tamanyu and Wood 2003) or of water at different temperatures, and the different means of thermal energy transfer (conduction, convection, advection) are in some cases distinguished (Tamanyu and Wood 2003). The effects of thermal blanketing and interaction with subsurface hydrosystems (cold aquifers) are mentioned for certain sites (Gandino, Guidi et al. 1985; Westercamp and Traineau 1987; Clemente and Villadolid-Abrigo 1993; Ingebritsen and Scholl 1993; Violette, Ledoux et al. 1997; Akasako, Matsuda et al. 2002; Tamanyu and Wood 2003), but always with a low degree of precision concerning the definition of the concerned aquifer structure and flow directions (the latter mostly as schematic arrows, and generally without individualizing the concerned aquifers), and, in most cases, without a precise quantification of the water fluxes between the geothermal aquifer and 
the surface (cold aquifers and/or surface waters). In several papers, the proposed diagrams suggest (through arrows for instance) the existence of significant fluxes (recharge, discharge) between the geothermal aquifer and the surface (see for instance (Gandino, Guidi et al. 1985; Ingebritsen and Scholl 1993)), but these important fluxes or, at the opposite the absence of significant fluxes, are rarely demonstrated. The quantification of such fluxes has only been performed for shallow low energy geothermal areas (see for instance (Dim et al. 2002; Kühn and Stöfen 2005; Flores-Márquez, Jiménez-Suárez et al. 2006)).

On active hot spot volcanoes such as the Fournaise volcano (Réunion Island (Violette, Ledoux et al. 1997) or Kilauea (Hawaii, (Ingebritsen and Scholl 1993)) the hydrogeological characterization is more advanced. Quantitative hydrogeological modelling of the upper permeable part of the edifice is carried out, which indirectly helps to reconstitute some of the characteristics of the underlying geothermal system, in particular the fact that infiltrating water is kept away from the magma chamber by a thick impervious shell surrounding the chamber (Violette, Ledoux et al. 1997), and that substantial variations in permeability and the presence of magmatic heat sources influence the structure and position of the fresh water salt water interface (Ingebritsen and Scholl 1993). On this basis, (Ingebritsen and Scholl 1993) proposed a general conceptual model of the Hawaiian volcanoes.

The present paper proposes a hydrogeological model of the Bouillante geothermal field, based on all available data at different scales. This synthesis is meant to improve our understanding of high energy geothermal fields, in particular those in an active andesitic type volcanic setting. Few publications present the structure and functioning of a high energy geothermal field in an integrated manner, from the heat source until the subsurface exchanges, whether natural (leaks through conduction, advection and convection) or Manmade (through boreholes), combining the characterization of the different energy transfer types within the various compartments of the subsurface with their structural and hydrodynamic (lithology, type of permeability, etc.) properties.

\section{Summary of the main works carried out in the Bouillante area}

The first exploration studies of the Bouillante geothermal field, financially supported by SPDEG (Société de Production d'Electricité de la Guadeloupe), were carried out by BRGM between 1963 and 1964 (Cormy, Demians d'Archimbaud et al. 1970; Demians d'Archimbaud and Munier-Jolain 1976; Demians d'Archimbaud and Surcin 1976). These studies mainly included geology and temperature gradient surveys in shallow drill holes. The thermal flow in the hottest area was close to $6.3 \mathrm{~W} / \mathrm{m}^{2}$, which represents hundred times the normal geothermal flow (Demians d'Archimbaud and Surcin 1976). These encouraging results decided the companies SPDEG and EURAFREP to carry on the exploration.

In 1970, following a geochemical study on the fluids of the thermal springs, three wells (BO1, BO-2 and BO-3; Figure 3, with respective depth of 800,338 and $850 \mathrm{~m}$ ) were drilled by EURAFREP. Among these wells, only BO-2 showed a capacity of large production of geothermal fluid $\left(240^{\circ} \mathrm{C}\right)$. In 1971 and 1974 , during two long term production tests, this well discharged a mixture of about 30 tonnes $/ \mathrm{h}(8 \mathrm{~kg} / \mathrm{s})$ of steam and 120 tonnes $/ \mathrm{h}(33 \mathrm{~kg} / \mathrm{s})$ of water after separation of these phases at 5 bars. In 1974, on the basis of geophysical surveys performed in 1972 and 1973, the well BO-4 (Figure 3) was drilled at a depth of 1,200 m. Even after its deepening down to $2,500 \mathrm{~m}$ in 1977 , the low steam output of this well was not considered economical. In 1974, a seismic reflection profile was also shot at sea along the whole western coast of Guadeloupe.

In 1980, EDF (Electricité de France) decided to build a pilot geothermal plant with a 4,5 MWe turbine (GB1) only feed by the BO-2 well. This experimental plant has been operating from 1986 to 1992 and was then stopped. Between 1980 and 1984, several 
geological, geophysical and geochemical exploration studies were carried out by BRGM (Barthes and Mennechet 1984; Gadiala and Westercamp 1984; Fabriol and Ouzounian 1985; Fabriol 2001; Sanjuan 2001).

In 1996, the Géothermie Bouillante company, created by CFG Services (60\%) and CHART (40\%), respective subsidiaries of the BRGM and EDF Groups, totally rehabilitated and brought back in service the GB1 plant for an industrial production of electricity. In 1998, the GB1 unit supplied $23 \mathrm{GWh}$ to EDF, which represented $2 \%$ of the annual electricity needs in Guadeloupe.

Between 1995 and 1999, BRGM and CFG Services undertook several research studies with the financial support of Géothermie Bouillante, European Union, Guadeloupe Regional Council and ADEME (Agency for the Environment and Energy Resources) in order to identify favourable areas for drilling new wells. Geological and geochemical studies showed that the main indices of geothermal activity were concentrated in and around the Bouillante Bay (Traineau, Sanjuan et al. 1997). They also allowed identifying the main faults. Submarine hydrothermal springs and gas escapes were discovered and mapped in the north of the Bouillante Bay (Sanjuan and Brach 1997; Sanjuan 2001; Sanjuan and Brach 2001). A relatively recent local volcanic activity was also evidenced $(<650,000$ years $)$. In 1998 , an experimental stimulation program of well BO-4 by thermal cracking induced through cold sea water injection increased its permeability and productivity (Correia, Sigurdsson et al. 2000; Sanjuan, Lasne et al. 2000).

After these studies, Géothermie Bouillante launched the Bouillante 2 project. In 2000 and 2001, three deviated wells (BO-5, BO-6 and BO-7; Figure 3) were drilled at depths close to 1,000-1,200 m. BO-5 and BO-6 discharged a geothermal fluid whose temperature was close to $250-260^{\circ} \mathrm{C}$ and whose chemical composition was similar to that analysed in the wells BO-2 and BO-4 (Sanjuan and Brach 2001). BO-7 was not productive. BO-2 was definitively disconnected from GB1 in 2002. After several production tests, the wells BO-5 and BO-6 were alternatively connected to the GB1 unit between 2002 and 2004 (Sanjuan, Traineau et al. 2005). During the second half of 2004, the wells BO-4, BO-5 and BO-6 were connected to GB1 (4.5 MWe) and GB2; the new GB2 unit (11 MWe) was brought in continuous service at the beginning of 2005 .

The Bouillante power plant, a double flash plant without reinjection, is the sole geothermal plant on the French territory. After phase separation in the High Pressure (HP) separator, the HP steam is distributed between the GB2 turbine and the HP level of the GB1 turbine. About a quarter of the separated water is vaporized in order to produce low pressure (LP) steam which feeds the LP level of the GB1 turbine. All the residual water is cooled below $40^{\circ} \mathrm{C}$ by mixing with sea water in a tank before being discharged to the sea.

In 2004, in the framework of the development of the Bouillante geothermal field (Bouillante 3 project), additional exploration studies, financially supported by Géothermie Bouillante, were carried out by BRGM and CFG Services with the future objective to drill new exploration wells in the north of the Bouillante Bay (Fabriol, Bitri et al. 2005; Sanjuan, Traineau et al. 2005).

\section{Geographical and geological setting}

\section{Location of the geothermal field - Surface morphology}

The Bouillante site is located on the Caribbean coast of Basse Terre Island (Figures 1, 2, 4 \& 5). The main active geothermal surface manifestations (hot springs, mud pools, steaming grounds and fumaroles), are located south of Bouillante Bay, around the geothermal power plant. Several submarine hot springs exist as well, especially north of Bouillante Bay in the 
Pointe à Lézard/Anse Marsolle area and have been extensively mapped, both on and offshore (Sanjuan 2001; Sanjuan, Lasne et al., 2001). Generally speaking, the surface thermal manifestations associated with the Bouillante geothermal system extend over a dozen kilometres along the coast and offshore, from Pointe de Malendure in the north until Anse Thomas in the south (Figure 4).

The west coast of this part of Basse Terre Island shows a relatively steep slope of around $30 \%$. Over a distance of about $3 \mathrm{~km}$, between the Faux Piton de Bouillante and the coast, elevations go from $900 \mathrm{~m}$ to sea level. This slope continues offshore (Figures 1, 4, 6 and 7), with a depth of over $2,000 \mathrm{~m}$ being reached only a few kilometres from the coast (Thinon, Bitri et al. 2004).

\section{Volcanism}

The Basse Terre volcanic island belongs to the recent Lesser Antilles volcanic arc (Andreieff, Bouysse et al. 1989). This arc, located on the north eastern edge of the oceanic Caribbean Plate (Figure 1), is the expression of Atlantic lithosphere subduction in a NE-SW direction, with a velocity of about $2 \mathrm{~cm} /$ year. The northern part of this arc is well known for its active volcanoes of Soufrière Hills in Montserrat, Soufrière in Guadeloupe, Montagne Pelée in Martinique, etc.

Basse Terre island, consisting exclusively of volcanic and volcanosedimentary rocks, was progressively built from the northeast to the southwest over roughly the past five million years. It comprises six main geological units (Boudon, Dagain et al., 1982):

1. The "basal complex", emplaced over $3.5 \mathrm{My}$ ago, is exposed at the northern tip of the island. It consists mainly of submarine volcanic and volcanosedimentary formations.

2. The "Northern massif" comprises submarine volcanic products and then subaerial formations that mark the emergence of the island. The extrusion of the Dôme des Mamelles (-1 My), northeast of the Bouillante site, materializes the end of this phase of volcanic activity.

3. The volcanism of the "Axial Chain", first submarine (hyaloclastites) and then mostly subaerial as shown by the massive superposed andesite flows of the Bouillante peaks, continued that of the Northern massif southward. It formed the central volcanoes of the island that constitute the geological substratum of the Bouillante area. These rocks were mostly emplaced around -1.5 My and $-1.25 \mathrm{My}$, but activity continued until about $-0.5 \mathrm{My}$ when the activity of the composite Sans Toucher volcano came to an end.

4. Erection of the "Monts Caraibes" created the southern tip of the island. Activity started with submarine basaltic volcanism of the Surtsey type, and finished around -0.5 My with explosive hydromagmatic activity and the subaerial effusion of domes and lava flows intercalated in phreatomagmatic products.

5. The "Bouillante Chain" is composed of a whole series of volcanic vents emplaced on the southwest (Caribbean) flank of the Axial Chain, from Baillif to north of Bouillante where the most continuous exposures are found, even though a few such vents also occur on the Atlantic side of the island. Their eruptive dynamics being mostly hydromagmatic, the vents emitted only small amounts of volcanic products. Their lava covers a wide range of chemical and petrographic compositions, from olivine basalt to dacite and quartz rhyolite. The chain was emplaced between about -0.8 to -0.6 My and continued up until the start of the erection of the Soufrière massif (-0.25 to $-0.14 \mathrm{My}$ ).

6. The last unit is that of the "Soufrière", the presently active volcano of Basse Terre Island in Guadeloupe. 
The subsurface of the Bouillante area is thus almost entirely composed of the volcanic formations of the Axial Chain, locally covered by vents belonging to the Bouillante Chain. Volcanic activity can be considered as having been almost continuous at the scale of geological time, since emplacement of the Bouillante Chain until the present day activity of the Soufrière volcano, whose main emission point is less than $15 \mathrm{~km}$ from the Bouillante site, the superficial magmatic chamber feeding this volcano being estimated at a $6 \mathrm{~km}$ depth below the summit of the volcano (Bernard, Molinié et al. 2006).

\section{Geological data from surface observations}

Geological surface observations at Bouillante (Sanjuan, Traineau et al. 2005) showed the extent in this area of the recent formations attributed to the eruptive products of the Bouillante Chain. They cover an area of 2 to $3 \mathrm{~km}^{2}$, mainly to the north of Bouillante Bay (Figure 3).

The vents mainly ejected andesitic pyroclastic products resulting from explosive activity: ash and lapilli falls and surges, and pumice flows and glowing cloud deposits, locally reworked into lahars. Two Strombolian cones and rare lava flows were identified as well. These recent formations are at most a few dozen metres thick and overlie with a normal contact the substratum composed of massive lava, pyroclastic deposits and eroded formations attributed to emissions of the Pitons de Bouillante stratovolcano (Axial Chain volcanism).

The Desmarais volcano (Figure 3) appears to be the most important of the Bouillante Chain. It had polyphase activity and varied dynamics (Plinian eruptions, glowing clouds, and lava flows). It also was the seat of the last known magmatic activity in the area, and it is thus tempting to propose the existence of a presently cooling magmatic intrusion below this volcano, which might be at the origin of the Bouillante geothermal anomaly.

\section{Geological data from wells}

At depth, the lithology of the volcanic formations is mostly known from data obtained in exploration and exploitation wells (Figures 5, 6 and 7) (Cormy, Demians d'Archimbaud et al. 1970; CFG 2001; Traineau 2001). Figure 7 illustrates the main type of geological data obtained from the boreholes. Three main units are identified, from bottom to top (Traineau 2001):

- the first stage of submarine activity in the Axial Chain, from 500 to $600 \mathrm{~m}$ depth until at least 2,500 $\mathrm{m}$ at the bottom of the deepest hole BO-4, consists of hyaloclastites intruded by rare subvertical dykes or submarine flows;

- a transition unit between submarine and subaerial volcanism, 200 to $350 \mathrm{~m}$ thick, mostly consists of brecciated formations (tuff, lahars, conglomerates, sandy horizons, shelly limestone) corresponding to shallow water deposits or coastal volcanism, alternating with lava that witnesses a more or less subaerial effusive activity;

- finally, over the first 250 to $300 \mathrm{~m}$ below surface, subaerial volcanic formations comprise successively (from the bottom up): a unit of 4 to 5 lava flows, each 20 to $100 \mathrm{~m}$ thick, intercalated with lahar levels each 10 to $30 \mathrm{~m}$ thick, overlain by lahars and conglomerates 30 to $130 \mathrm{~m}$ thick, depending on the borehole. The last unit was the result of rapid erosion of the Pitons de Bouillante volcano in the Axial Chain, associated with huge collapse events.

No precise element is available for dating the various formations of the wells, but all available geological data point at them being part of the Axial Chain volcanism.

The fact that the transition from submarine to subaerial volcanism is located at least $450 \mathrm{~m}$ below present day sea level, suggests that the region was subjected to significant negative 
vertical movement since the emplacement of these formations. This agrees with the graben structure proposed by (Feuillet, Manighetti et al. 2002) and described hereafter.

\section{Structural setting}

At a regional scale (Feuillet, Manighetti et al. 2001; Feuillet, Manighetti et al. 2002), the structure of the Bouillante area is marked by (Figure 2):

- east - west oriented graben type structures with a generally steep southerly dip. They extend from the south of Basse Terre until beyond Marie Galante;

- the Basse Terre/Montserrat normal fault system, NNW-SSE oriented.

Field observations around Bouillante (Sanjuan, Traineau et al. 2005) have confirmed this general scheme. The recent formations and outcrops of the older substratum (Figures 3 and 5) show almost exclusively open east - west structures (normal faults, and traction cracks lacking indicators of significant movement, subvertical, and dipping mainly southward), associated or not with present day or past traces of hydrothermal circulation.

Only one large (E-W) fracture corridor is seen at outcrop (the Cocagne fault); this is probably because either others exist but are masked by recent volcanic formations, or this is the only fault that is regularly reactivated (due to tectonic or hydraulic influence) and thus receives sufficient fluid circulation (although low in absolute value) to reach the surface.

Rare $\mathrm{N} 120^{\circ} \mathrm{E}$ to $\mathrm{N} 160^{\circ} \mathrm{E}$ fractures are only found in the oldest formations of the Axial Chain. This roughly northwest direction, quite common offshore (Thinon, Bitri et al. 2004) and close to the orientation of the regional Montserrat /Basse Terre fault, seems to witness an older, or less active, fracturing episode, essentially affecting the old formations of the Axial Chain that are exposed on the sea floor and masked by the recent Bouillante chain products.

\section{Hydrodynamic properties - Groundwater flow}

\section{Roles of fractures in the hydrodynamic properties of the geological formations}

The hydrodynamic properties, in particular permeability, are mostly known from observations during drilling (Figure 7). These cover the location and quantification of levels with partial or total mud loss (Cormy, Demians d'Archimbaud et al. 1970; CFG 2001; Sanjuan, Le Nindre et al. 2004). These observations were confirmed in certain wells by thermometric profiles run after injection of cold water within the aquifer (the cooled areas after water injection allowing to locate the permeable zones of each well).

These data show that:

- $\quad$ all the wells except BO-7 intersected permeable intervals;

- except well BO-2, the only one to intersect a shallow aquifer consisting of marine sand, all permeable intervals appear below at least $400 \mathrm{~m}$ depth below sea level;

- some of the permeable intervals intersected in wells are isolated (over only a few metres thickness). However, in all productive wells, there are at least several tens of metres and even a few hundred metres thick permeable intervals; in wells BO-4 and BO-5, the cumulated length of these permeable intervals exceeds $300 \mathrm{~m}$. These permeable intervals show a heterogeneous distribution of the local permeabilities, as alternating highly permeable and less permeable levels;

- no obvious relationship was found between the original lithology of the rocks and their permeability. The larger permeable intervals can consist of several rock types. Fracturing 
appears to have a similar effect, from a hydrodynamical standpoint, within the different types of geological formation intersected by the wells: for example, the fractures developed within competent rocks (e.g. lava) present permeability characteristics that are similar to those affecting rocks that are theoretically less favourable, for example due to a higher clay content (e.g. lahars);

- most permeable intervals intersected in boreholes could be correlated with faults observed at the surface.

Compilation and synthesis of these data provide the following main results (Figure 8):

1. The geological formations that may have had a significant original permeability (in particular lava that, at the surface, has a well developed fissuring with flow and cooling figures (Lachassagne and Maréchal 2004; Lachassagne, Blavoux et al. 2006) occur exclusively in the first few hundred metres below the surface. However, this original permeability has been completely obliterated. Exhaustive analysis of clay minerals from wells BO-5 (Figure 7), BO-6 and BO-7 (Mas, Guisseau et al. 2006; Guisseau, Patrier Mas et al. 2007) and from surface samples (Patrier, Beaufort et al. 2003) shows that this obliteration can be explained by self sealing processes related to the alteration by circulation of hydrothermal fluids (smectite type clays down to about $250 \mathrm{~m}$ depth, partially replaced by kaolinite from $150 \mathrm{~m}$ down and, lower down, interbedded illite smectite). As the geological formations that had significant original permeability are at shallow depth within this particularly clogged zone, the geothermal system no longer comprises formations with a significant matrix or fissure permeability. This point is indirectly confirmed by surface geophysical measurements: deep Electrical Resistivity Tomography profiles show very low resistivity areas in the first hundred meters below the surface (Fabriol, Bitri et al. 2005);

2. The wells thus intersect only a fracture permeability. The hydrodynamic interpretation of interference between the wells confirms this point: flow dimensions close to 1, as deduced with the method developed by (Barker 1988), confirm the existence of one or more major planar structures, i.e. of the fracture type, within which most of the flow occurs (Lachassagne and Maréchal 2004).

3. The fracture permeability itself is subject to obliteration through self sealing. Hydraulically speaking, it only becomes efficient from 400 to $500 \mathrm{~m}$ below sea level downward, which explains the low flow rate of hydrothermal fluid leaks observed in surface (see below).

4. The fractures are of tectonic origin. Hydraulic fracturing processes, partly related to pressure buildup associated with the selfsealing phenomena described above, probably exist; surface indications such as anastomosing structures with a variable geometry, have been seen in outcrop (Sanjuan, Traineau et al. 2005). Certain fractures intersected in wells could be correlated with the east - west faults identified at the surface (Figures 3 and 5) (Genter and Traineau 2004; Sanjuan, Le Nindre et al. 2004). For instance, the Cocagne fault (Figure 5), which coincides with the area where the strongest hydrothermal surface features of the entire Bouillante site occur, is intersected by wells BO-5 and BO-6. The permeable zone is extensive and its vertical projection confers it a width of around $100 \mathrm{~m}$, which means that the fracture zone must be at least several tens of metres wide. Wells BO-5 and BO-6 also intersected the Plateau fault that has there a lower permeability (sealed zone), as the holes intersected it at shallower depth than the Cocagne fault. 
5. The downward extension of these permeable fractures is unknown, but they must extend to at least 1,100 m below sea level (the deepest permeable zone identified in a borehole), which is most likely a default estimate that is far removed from reality.

6. Such fractures are relatively numerous as they are intersected by most wells.

7. Hydrodynamic interpretation of the interference between production wells (Lachassagne and Maréchal 2004; Sanjuan, Le Nindre et al. 2004), in particular between BO-4, BO-5 and BO-6, requires considering not only the east-west fracturing, but also the existence of almost perpendicular, thus roughly N-S fracturing, the interference being similar between two wells located on the same east west fracture and two wells located on two different east west fractures. The second fracture network identified in the Bouillante region (the Montserrat / Basse Terre fault system) thus probably has, at depth, similar permeability properties to those of the east west fault system. The results obtained from two long term production tests carried out in 1971 and 1974 (6 months) on the well BO-2 that showed that the major drain of this well (the Cocagne fracture) also communicated with "a relatively high capacity reservoir" (Demians d'Archimbaud and Munier-Jolain 1976) are consistent with this hypothesis.

8. These two relatively dense fracture networks form a geothermal aquifer with good hydrodynamic properties (high flow rates from the wells, low amplitude interference measured in the observation wells located at a distance of 300 to $400 \mathrm{~m}$ ), which extends from around $500 \mathrm{~m}$ below sea level to a depth of several kilometres. The equivalent transmissivity (for pure water at $25^{\circ} \mathrm{C}$ ) of the aquifer tapped by wells BO-5 and BO-6 is evaluated to be 2 to $4.10^{-3} \mathrm{~m}^{2} / \mathrm{s}$ from hydrodynamic interpretation of the interference between production wells.

\section{Hydrogeological functioning of the geothermal aquifer}

\section{Composition and origin of the geothermal fluid}

Geochemical characterization work provided the following main information:

1. The waters collected from hot springs, which are $\mathrm{NaCl}$ fluids and whose salinity is higher than $1 \mathrm{~g} / \mathrm{l}$ (submarine springs, "Thomas, Cave BO-2, Bord de Mer and the neighbouring drillhole BO-BS drilled since 1999, Tuyau, Marsolle" springs - Figure 4), are a mixture in variable proportions of surface waters (fresh and/or sea water), and the deep geothermal fluid (Sanjuan, Lasne et al., 2001). The other thermal waters $\left(\mathrm{Na}-\mathrm{HCO}_{3}\right.$ fluids with a salinity $<1 \mathrm{~g} / \mathrm{l})$ such as those collected from the springs "Bain du Curé, Lise or River Bouillante" (Figure 4) are only surface fresh waters heated by conduction (Mas, Guisseau et al. 2006).

2. The water flowing through the geothermal aquifer, whether sampled in wells or reconstituted from the geothermal contribution to hot springs waters, has a homogeneous composition at the scale of the Bouillante region (Sanjuan and Brach 1997; Traineau, Sanjuan et al. 1997; Sanjuan, 2001; Sanjuan, Lasne et al., 2001; Sanjuan, Le Nindre et al. 2004), at least from Malendure in the north until Thomas in the south (Figure 4). This $\mathrm{NaCl}$ fluid, with a salinity of about $20 \mathrm{~g} / \mathrm{l}$ and a pH value close to $5.3 \pm 0.3$ at $250-260^{\circ} \mathrm{C}$, is the result of the mixing of about $60 \%$ sea water and $40 \%$ fresh water ( Sanjuan, 2001; Sanjuan, Lasne et al., 2001; Sanjuan, Le Nindre et al. 2004). The amounts of non condensable gases associated to this fluid are low (0.4\% in mass in the wells). These gases are essentially constituted of $\mathrm{CO}_{2}(>90 \%$ in volume). Their isotopic signatures (13-carbon and ${ }^{3} \mathrm{He} /{ }^{4} \mathrm{He}$ ) indicate magmatic, marine and atmospheric origin. Geochemical and 
thermometric data show that, under the pressure and temperature conditions within the aquifer, the reservoir only contains water and, specifically, no steam.

3. At high temperatures, the geothermal fluid often shows an 18-oxygen enrichment caused by interaction with volcanic rocks. The absence of this enrichment in the Bouillante geothermal fluid and its residual marine $\delta^{34} S$ signature suggest a high water rock ratio in the deep reservoir. The geothermal fluid reacts with the surrounding volcanic rocks reaching chemical equilibrium at about $250-260^{\circ} \mathrm{C}$ with respect to a mineral assemblage as shown by its composition and by saturation calculations ( Sanjuan, 2001; Sanjuan, Lasne et al., 2001; Sanjuan, Le Nindre et al. 2004). Compared with a diluted sea water, the geothermal fluid is depleted in $\mathrm{Mg}, \mathrm{SO}_{4}, \mathrm{HCO}_{3}, \mathrm{Na}$ and is enriched in $\mathrm{K}, \mathrm{Ca}, \mathrm{Si}, \mathrm{B}, \mathrm{Li}$, $\mathrm{Sr}, \mathrm{Ba}, \mathrm{Mn}, \mathrm{Cs}, \mathrm{Rb}, \mathrm{As}$ and trace metal ions. Its ${ }^{87} \mathrm{Sr} /{ }^{86} \mathrm{Sr}$ signature (close to 0.705 ) also characterises an equilibrium state with volcanic rocks (andesite or basalt). These results and the low tritium contents measured in the geothermal fluid suggest a relatively long residence time of the water in the geothermal aquifer (> 100 years). The convergence of the geochemical and gas thermometer data toward a maximum equilibrium temperature of around $250-260{ }^{\circ} \mathrm{C}$ and the geochemical homogeneity of the fluid indicates the existence of homogeneous processes at the scale of the field.

4. These results are in good agreement with inter well tracer studies that suggest a large interconnected reservoir volume (> 30 millions $\mathrm{m}^{3}$; (Sanjuan, Le Nindre et al. 2004)). The large reservoir volume is also supported by the temporal stability of the chemical and isotopic composition of the geothermal fluid discharged from the wells (Sanjuan, Le Nindre et al. 2004) until now, 5 millions tons of fluid being produced yearly since 2005 , and a total of approx. 20 millions tons having now been produced from the field.

\section{Hydraulic heads in the geothermal aquifer}

The hydraulic head prevailing within the geothermal aquifer is estimated at about $150 \mathrm{~m}$ above mean sea level (of equivalent freshwater) from pressure measurements performed in the wells BO-4, 5 and 6 after an eleven year long period without production.

As a consequence of the low number of wells reaching the aquifer, and the energy production constraints, no piezometric map is available. Nevertheless, a recent tracer test (2007) with injection at BO-2 and restitution observed (first in BO-6, then in BO-4) at 2 of the 3 discharging wells and no restitution at $\mathrm{BO}-5$, the $3^{\text {rd }}$ discharging well, shows that the artificial discharge from the aquifer significantly imprints the flow pattern inside it. Drawdowns (pressure drop) however remain quite low (less than 4 to 4.5 bars at the wells) in the aquifer.

\section{Tentative water budget of the geothermal aquifer}

In view of the large volume of the aquifer, the absence of significant natural fluctuations of its hydraulic head, it can be assumed that the geothermal aquifer was operating in a steady state regime from a hydraulic viewpoint before its recent larger exploitation, i.e. the sum of geothermal fluid leakage balances the inflow of cold water (both continental fresh and marine water).

Because of the selfsealing processes in the top part of the aquifer and, very likely, around it at the edges of the hot area, and because of the absence of fluid exchanges with the underlying rocks (water nor gases), the outflow of the geothermal aquifer is concentrated in its roof. The flow of geothermal fluid from springs (leaks through fractures) thus provides a good estimator for this outflow. 
Most of the hot springs of the Bouillante area emerge currently either close to the coastline or offshore, where they were extensively mapped (Sanjuan and Brach 1997; Sanjuan 2001; Sanjuan, Lasne et al., 2001), and not inland. This location appears to be logical both from a structural standpoint (main faults) and from a hydrodynamical standpoint, the shore forming the present day regional base level (Figure 3 and Figure 4). There, the emergence of fluids (from permeable structures that are not entirely clogged by selfsealing and from cold superficial aquifers only partly influenced by thermal waters) requires the least energy (potential and thermal) to outflow. The location of hot springs near the coastline and offshore agrees with the fact that the faults permeable near the surface, which are the locus of hot fluids that rise up to the surface, are mostly perpendicular to the coastline, i.e. E-W. In fact, structures with only a N-S direction would be at the origin of inland hot springs, located where these structures parallel to the coast intersect the valleys (ravines).

The flow rates of all springs with a thermal component are low (Table 1), from 1 to $10 \mathrm{l} / \mathrm{min}$ for those springs for which an estimate is available, or about 0.06 to $0.6 \mathrm{~m}^{3} / \mathrm{h}$. The total known or estimated flow rate of such springs (Table 1) is around $4 \mathrm{~m}^{3} / \mathrm{h}$. A grand total of between 10 and $100 \mathrm{~m}^{3} / \mathrm{h}$ (20 to 200 times the flow rate of the Marsolle spring, the one with the highest recorded flow) can be assumed as a maximum for all hot springs combined, including submarine ones.

\begin{tabular}{|l|c|c|c|c|c|}
\hline \multicolumn{1}{|c|}{ Hot springs } & Ref. & $\begin{array}{c}\text { T } \\
{ }^{\circ} \text { C }\end{array}$ & $\begin{array}{c}\text { Approx. flow } \\
\text { 1/min }\end{array}$ & $\begin{array}{c}\text { BO-2 fluid } \\
\text { (\%) }\end{array}$ & $\begin{array}{c}\text { BO-2 fluid } \\
\text { (1/min) }\end{array}$ \\
\hline Bain Curé (BC) & $\mathbf{9 6 0 1}$ & 39.0 & 2 & $\sim 0$ & $\sim 0$ \\
Lise (L) & $\mathbf{9 6 0 3}$ & 35.7 & n.a. $(\sim 10)$ & $\sim 0$ & $\sim 0$ \\
Cave BO-2 (CBO2) & $\mathbf{9 5 0 4}$ & 97.4 & n.a. $(\sim 1)$ & 82 & $\sim 0.82$ \\
Maison Cabarrus (MC) & $\mathbf{9 6 1 7 A}$ & 97.3 & n.a. $(\sim 1)$ & $\sim 0$ & $\sim 0$ \\
Ravine Blanche (RB) & $\mathbf{9 6 1 8}$ & 29.2 & very low & $\sim 0$ & $\sim 0$ \\
Tuyau (Ty) & $\mathbf{9 6 1 9}$ & 60.5 & 3.1 & 4.5 & 0.14 \\
Thomas (Th) & $\mathbf{9 6 2 0}$ & 54.6 & n.a. $(\sim 10)$ & 10 & $\sim 1$ \\
Ravine Renoir (downstream) & $\mathbf{9 6 2 1}$ & 36.9 & n.a. & 0 & 0 \\
Ravine Renoir & $\mathbf{9 6 2 2}$ & 29.2 & n.a. & 0 & 0 \\
Bord de Mer (BM) & $\mathbf{9 6 2 4 A}$ & 81.0 & n.a. $(\sim 1)$ & 66 & $\sim 0.66$ \\
River Bouillante (upstream) (RBAM) & $\mathbf{9 6 2 6}$ & 29.6 & 2.7 & $\sim 0$ & $\sim 0$ \\
Marsolle (M) & $\mathbf{9 6 2 7}$ & 44.3 & 10 & 1.9 & 0.2 \\
Pointe à Lézard (PL) & $\mathbf{9 6 2 8}$ & 92.0 & n.a. $(\sim 10)$ & 38 & $\sim 3.8$ \\
Ilet Pigeon (IP) & $\mathbf{9 6 2 9}$ & 52.0 & n.a. $(\sim 10)$ & 7 & $\sim 0.7$ \\
Total & & & $(\sim 60)$ & & 7.3 \\
\hline
\end{tabular}

Table 1: Flow rates and contribution of geothermal fluid (BO-2 type) of hot springs in the Bouillante area.

The contribution of geothermal fluid is quite small in most of the terrestrial springs (mostly below $10 \%$, e.g. $2 \%$ for the Marsolle spring). For the submarine hydrothermal springs or the thermal spring "Cave BO-2", this contribution is a bit higher. On a basis of a mean $10 \%$ contribution of the geothermal fluid to the springs, the leakage volumes from the geothermal aquifer can thus be estimated between 1 and $10 \mathrm{~m}^{3} / \mathrm{h}$ at most.

As the geothermal fluid is composed of $40 \%$ fresh water and $60 \%$ sea water, the contribution of meteoric origin to the aquifer must be 0.4 to $4 \mathrm{~m}^{3} / \mathrm{h}$. Related to an infiltration area of a dozen square kilometres for the surface catchment area potentially supplying the aquifer on land - a rough hypothesis that reduces this surface area to a minimum as most recharge takes probably place at the edges of the geothermal reservoir where downward flows may occur this represents a (thus overestimated) rainwater flux of between 0.4 and $4 \mathrm{~mm} /$ year.

This flux is extremely low when compared with the effective rainfall (rainfall minus real evapotranspiration) available for the hydrological basins of the area (on the west side of Basse 
Terre, the effective rainfall ranges from $1000 \mathrm{~mm}$ per year in the near vicinity of the shore and increases very rapidly to reach $5,000 \mathrm{~mm} /$ year at $1,000 \mathrm{~m}$ elevation) and compared to the great potential differences existing between the slopes and the coastal area. This very low value for the recharge of deep hot aquifers is coherent with subsurface hydraulic conductivity data and with the results of hydrological and hydrogeological modelling (global lumped model) of the catchments in the Bouillante area that do not require the existence of significant deep leaks nor inflows (modelled catchments are the Lostau and Beaugendre rivers, respectively at the hydrometric stations "Déversoir" at $60 \mathrm{~m}$ elevation, and "Cote 77 " at $77 \mathrm{~m}$ elevation) (Lachassagne and Maréchal 2004)).

This natural flux $\left(0.4\right.$ to $\left.4 \mathrm{~m}^{3} / \mathrm{h}\right)$ is quite low compared to the water abstraction for energy production (500 t/h of vapor as a mean). It implies both destorage within the aquifer and, as drawdown remain quite low, leakage from the semipervious neighbor geological formations.

\section{Temperature distribution - Conduction and convection processes}

Figure 9 presents an example of equilibrium temperature profiles measured in the Bouillante wells (integrating the correction for well deviation) as well as one section through wells BO2, BO-4, BO-6 and BO-7. As the reservoir has a fracture permeability, such profiles and crosssections only show an overview of the real temperature distribution.

The general aspect of all profiles is typical of that measured in most geothermal fields, with a high and stable gradient in the shallow part, followed by a regular decrease in the gradient, and finally a third zone where the temperature shows little variation over several hundreds of metres, or even kilometres. These elements suggest the presence of a deep convection system (zone with a null gradient), relayed by heat exchanges dominated by conduction at shallower depth (Guillou-Frottier 2003). Convection requires a significant permeability of the concerned horizon. Within this aquifer, hot water rises whereas cold water descends; this process allows an efficient heat transfer between the top and the bottom of the horizon in question, water playing a role of heat exchange fluid.

Calculation of the Rayleigh number according to the equation of (Combarnous and Bories 1975), which assimilates as a first approximation the reservoir to an equivalent porous medium, and using the most probable hypotheses for the geometry of the system, suggests that the geothermal reservoir of Bouillante is favourable for the creation of convection cells. The Rayleigh number obtained is around 5000, which is two orders of magnitude larger than the critical value of 40 . Sensitivity analysis shows that Rayleigh numbers much higher than the convection threshold are obtained for all configurations than can be envisaged: low temperature difference $\left(60{ }^{\circ} \mathrm{C}\right)$ between top and bottom of the aquifer; relatively thin aquifer $(1000 \mathrm{~m})$; relatively low intrinsic permeability (at constant transmissivity equal to that deduced from the interference tests); relatively wide permeable fractures. The thermal conductivity used is that of acid or basic rocks at $250{ }^{\circ} \mathrm{C}$ (Vosteen and Schellschmidt 2003). The main factor explaining the appearance of convection is the fracture permeability.

This result forms an element of confirmation of the geological and hydrogeological hypotheses mentioned above. We can thus state that at Bouillante:

- between the surface and the reservoir (above 400 to $500 \mathrm{~m}$ depth, where the fractures forming the geothermal aquifer deeper down are clogged):

○ the rocks play a role of "thermal blanketing", commonly assimilated with an effect of thermal insulation. These rocks are not strictly speaking "insulating", as their thermal conductivity is similar to that of the rocks of the underlying aquifer. We are thus dealing with an impermeable cover, rather than a thermal blanket, heat transfert 
through conduction being much less efficient than transfer through convection. In other words, the hot deep fluids remain blocked under the "cover" thanks to permeability contrasts between the different formations. The accumulated heat within the reservoir diffuses toward the surface mainly through conduction, fluid losses being very low at the scale of the aquifer. This last phenomenon explains the shape of the geotherm curve in the intermediate zone, noted (2) on Figure 9 (Guillou-Frottier 2003);

○ temperature distribution is locally influenced by the faults, among others by the major structure formed by the Cocagne fault. Their clogging being only partial, they are a (low efficiency) water and thus heat vector, by convection, toward the subsurface.

- Beyond $500 \mathrm{~m}$ below sea level, within the geothermal aquifer (see for instance Figure 9, right):

$\circ$ the temperature is around $250-260^{\circ} \mathrm{C}$ within the reservoir (Guillou-Frottier 2003). The mixing of hot and cold fluids through convection leads to good homogeneization, which is shown by an almost null thermal gradient that locally can even be negative;

0 the permeable zones (fractured areas intersected by the boreholes) host fluids with a relatively low temperature $\left(230^{\circ} \mathrm{C}\right.$ ) as well as hotter fluids (about $250-260^{\circ} \mathrm{C}$ ), depending upon whether the wells intersect fractures driving ascending or descending branches of the convection cells.

- Below the footwall of the geothermal reservoir (not reached by the wells) lie rocks with low permeability, either without fractures or with fractures that are little permeable, which ensure, through conduction, the heat transfer from the heat source to the geothermal reservoir. In fact, geochemistry has shown the absence of any contribution of fluids other than those of the aquifer and the gas transfers are also very low.

\section{Discussion - Hydrogeological model of the high energy Bouillante geothermal field}

After summarizing all the above mentioned information, we were able to propose a hydrogeological conceptual model describing, according to the current state of knowledge, the structure and hydrodynamical functioning of the Bouillante geothermal field.

The geological and hydrogeological structure of the geothermal field is described in depth within sections 3. and 4. (Figure 6).

\section{Hydrodynamic properties and vertical extent of the geothermal aquifer}

The geothermal aquifer presents exclusively fracture permeability (Figure 8), with two main groups of fractures:

- E-W fractures affecting both the older formations at depth and the more recent overlying rocks. They belong to the northern slope of the Basse Terre / Marie Galante graben (Figure 2) and are compatible with an overall N-S extensional component;

- sub N-S fractures (whose origin is related to the Montserrat / Basse Terre fracture system) and, possibly, to collapse due to the morphological asymmetry of the island).

The permeability of the E-W fractures is similar to that of the N-S fractures. Fracturing has a similar hydrodynamical effect within the different lithologies. At depth, the permeable zones correspond to fracture corridors several tens of metres thick. 
Due to self sealing, the top of the resulting geothermal aquifer lies at a depth of between some 400 and $500 \mathrm{~m}$. The upper formations present a very low permeability, both primary (where any) and fracture permeability being quite completely clogged. The natural outflow of thermal water is thus localised (springs in the major fault corridors) and has a low discharge.

The lower boundary of the aquifer is assumed to lie at a depth of at least several thousand metres. Structural reconstructions and strain modelling (including fluid pressure), to be performed in the future, or even hydrogeochemistry will contribute to evaluate this depth.

\section{Hydrogeological and geothermal functioning of the aquifer}

The distribution of vertical permeability described above is responsible for the existence and the dynamics of the geothermal system (Figure 8):

- the permeable aquifer zone contains hot waters with a relatively homogeneous temperature (about $250-260^{\circ} \mathrm{C}{ }^{\circ} \mathrm{C}$ ). Water circulation is controlled by convection. At least for the southern part of the geothermal reservoir (around the town of Bouillante), the E-W and N$\mathrm{S}$ trending fracture networks are well connected and contribute to a 'broad' functioning of the reservoir, rather than a partitioning per individual fracture zone. The homogeneous nature of the geochemical data available at the scale of the entire Bouillante region suggests strongly that this 'broad' behaviour can be extended to the entire geothermal reservoir, such as its perimeter is understood from surface expressions;

- this aquifer is separated from the surface (thermal blanketing) by the above described low permeability formations that restrict almost entirely any heat exchange with the surface to the process of conduction. The presence of this thermal blanket is the main factor explaining the durability, on a geological time scale, of the geothermal system. Along with convection within the geothermal aquifer, this also explains the relative homogeneous temperature of the fluids. Geothermal systems within which convection processes are active up until the topographic surface have consequently a short life span and are thus few on the Earth's surface;

- the wall of the geothermal aquifer is in contact with low permeability formations that transfer heat from the heat source by conduction;

- it is tempting to position the heat source (a magmatic intrusion undergoing cooling, the initial temperature of which was some $900^{\circ} \mathrm{C}$ ) beneath the Desmarais volcano (Figure 3).

The geothermal aquifer, because of its low permeability 'cover', undergoes a very little leakage, of the order of $1-10 \mathrm{~m}^{3} / \mathrm{h}$ at the most. This leakage is reflected by the presence of thermal springs, mainly located along the coast or offshore; this does not, however constitute sufficient evidence to restrict the extent of the geothermal reservoir to the marine domain.

This leakage is compensated by a similar recharge volume composed of about $40 \%$ meteoric water infiltrated through the continental domain of the aquifer, and $60 \%$ sea water infiltrated through the marine domain. Recharge of the geothermal aquifer by fresh water $(0.5$ to $5 \mathrm{~m}^{3} /$ hour at the most) represents only a very small fraction of the supply of the aquifers (mainly subsurface aquifers): a few millimetres a year maximum, for a total recharge estimated at 150 to $400 \mathrm{~mm} /$ year depending on the catchment. Within any theoretical cross section in the geothermal aquifer, the groundwater flux associated with convection must be considerably greater than the leakage flux of the aquifer towards the surface (and thus of the influx - or recharge - to the aquifer). The water stored within the permeable parts of the aquifer (several tens to hundreds of millions of $\mathrm{m}^{3}$ ) is several orders of magnitude greater than the annual leakage flux (less than 10,000 to $100,000 \mathrm{~m}^{3} /$ year) which, under natural conditions 
(i.e. no exploitation), leads to an average renewal rate of the order of several hundred to several tens of thousands of years.

From the inferred distribution of hydraulic heads within the Bouillante area (this hydraulic head distribution resulting from the potential energy of water, the various flows and their associated head losses, but also from the input of thermal energy), a tentative conceptual scheme of the water flow lines, and thus of both the recharge (downflow) and discharge (upflow) areas is proposed (Figure 10) under natural conditions. Logically, the recharge of the geothermal aquifer occurs at the periphery of the heated area whereas its discharge takes place at its top. This scheme is in accordance with the mixing of fresh water of inland origin and of sea water, without the need of a freshwater/salt water wedge (classical sharp interface between fresh and marine groundwaters) within the geothermal aquifer.

Except for the impact of pumping by the geothermal power plant, the system operates in a steady state hydraulic regime and is not significantly influenced by surface hydrological conditions, mainly because of the low permeability of the aquifer cover. If the heat source and/or fracturing are recent on a geologic time scale (relatively to the inertia of the system), then the system may not yet have reached thermal equilibrium (Maréchal, Perrochet et al. 1999). The flow and thermal numerical modelling of this scheme (Figure 10) will later help in the parameterisation of the various processes, geometries and fluxes involved in the Bouillante geothermal field.

On the basis of a network of orthogonal permeable fractures, the convection cells within the aquifer may have a relatively regular spatial distribution. The thermometric data available for BO-4 (downward circulation via a probable N-S oriented fracture), BO-5 and BO-6 (upward circulation via an E-W trending fracture, the Cocagne fault) suggest that the fracture nodes could alternatively, spatially, be drainage sites with a vertical component that is respectively ascending and descending. The fractures located between each node would be associated with a convection cell and every half fracture would thus be the site of drainage with an alternating ascending and descending vertical component.

Considering the high hydraulic head throughout the aquifer, and especially the high temperature of the geothermal fluid whether this be within the ascending or descending branches, as well as the low volume of leakage towards the surface, it is unlikely that the spatial distribution of the surface thermal springs (or the thermal springs with a strong influence of deep fluids) respects this convection cell arrangement. At the scale of the Bouillante region, the perimeter delimiting the presence of surface thermal manifestations basically corresponds to that of the heated part of the geothermal reservoir. Recharge is mainly diffuse and along the edge where, due to a lower contribution of geothermal energy, the hydraulic head is lower within the geothermal aquifer enabling a downward vertical drainage from the overlying formations. The relative percentages of sea water and fresh water (respectively about 60 and 40\%) suggest that the maximum extension of the deep aquifer (both its heated part and the less heated one) is relatively balanced beneath the sea and the emerged part of Basse Terre, thus centered approximately along the coastline.

\section{Origin and location of the geothermal field}

On a smaller scale, two main factors both essential, explain the existence and location of the Bouillante geothermal field (Figure 11):

- the presence, location and volume of a heat source (magmatic intrusion),

- the presence of a network of permeable fractures at the origin of the aquifer (and that may also be at the origin of the magmatic intrusion). 


\section{Hydrogeological setting of the subsurface}

In the subsurface, the hydrogeological characteristics of the Bouillante area are typical of an andesitic type volcanic region, composed of relatively recent formations, thus little affected by meteoric weathering, subjected to a humid tropical climate. The aquifers are hosted by certain favourable geological formations from a lithological standpoint (lava flows, scoria cones, alluvium). These superficial aquifers often serve, but not exclusively (cold springs without any geothermal influence and thermal springs not related to subsurface aquifers are also existing), as a link with respect to the surface hydrothermal manifestations (thermal springs whose water is heated by convection and/or conduction). The hydraulic and thermal relationships between the geothermal aquifer and the superficial aquifers are limited, mainly because of the shallow nature of the surface aquifers and the low permeability cover that blankets the geothermal aquifer.

\section{Conclusions}

The multidisciplinary approach adopted in the present study, integrating several disciplines including geology, hydrogeology, hydrogeochemistry, and analysis of temperatures at depth, surface manifestations, and surface and subsurface data acquired at various scales, allows us to propose a hydrogeological model based on a physical and genetic description of the Bouillante geothermal field and the various processes governing it.

The study shows that the origin of this field, as with most high energy geothermal fields, lies in the coexistence of three factors, all necessary and not sufficient individually, that have been identified for the Bouillante site:

1. the presence of a source of heat,

2. the existence of a fracture network near this heat source constituting an aquifer that is capable of storing a large volume of water and, consequently, heat, and transferring this from the deep subsurface upwards and making it accessible for geothermal exploitation,

3. an impermeable (and not really an insulating) surface cover, limiting the loss of energy to only conduction, and ensuring the durability of the field at the geological timescale. One important point to be stressed out is thus the fact that the water fluxes exchanged between the geothermal aquifer and the subsurface appear to be very limited. This result should be kept in mind when dealing with most of the high energy geothermal fields.

Nevertheless, even if opens up numerous perspectives in operational terms (management of the existing set of wells, fluid reinjection, investigation for further development of the field, etc), this proposed conceptual model represents only the first step towards the understanding of how the geothermal field functions. It is the necessary stage prior to digital, hydraulic and thermal modelling of the field, which is expected to consist of two stages:

- preliminary modelling intended to confirm and, if need be, modify or refine the present conceptual model. The aim in particular will be to clarify, by means of a sensitivity analysis, whether or not the system operates under a steady state regime, the depth of the wall of the aquifer, the depth (and if possible the location and the characteristics) of the heat source and heat flux within the various horizons, the reservoir volume, etc.,

- operational modelling intended to optimize exploitation methods. 
Indeed, mathematical models constitute not only management support tools, but also tools that can help further our understanding of physical processes.

The lower boundary of the geothermal aquifer has not yet been clarified. Therefore, deep geophysical (Magneto Telluric) surveys could also be very useful to investigate deeper areas of this aquifer and extend the data obtained by the electrical profile carried out in 2004.

\section{Acknowledgments}

The authors thank ADEME (Agence de l'Environnement et de la Maîtrise de l'Energie) and Geothermie Bouillante Ltd for supporting this research under various funding projects (particularly ADEME grants $\mathrm{N}^{\circ} 0205035$ and 0205036 Geothermie Bouillante grant RPI $\mathrm{N}^{\circ}$ 141). The authors also thank Geothermie Bouillante Ltd and CFG Services for site facilities and technical and scientific support. Dr H. Traineau is particularly thanked for the fruitful discussions in the field and for his manuscript review. B. Aunay is thanked for his help for the drawing of some illustrations.

\section{References}

Akasako, H., K. Matsuda, K. Tagomori, T. Koseki, H. Takahashi, S. Dwipa and H. c. Muraoka (2002). "Conceptual models for geothermal systems in the Wolo Bobo, Nage and Mataloko fields, Bajawa area, central Flores, Indonesia; Indonesia-Japan geothermal exploration project in Flores Island." Chishitsu Chousa Kenkyuu Houkoku = Bulletin of the Geological Survey of Japan 53(2-3): 375-387.

Andreieff, P., P. Bouysse and D. Westercamp (1989). Géologie de l'arc insulaire des petites Antilles et évolution géodynamique de l'Est-Caraïbe, BRGM Document N171.

Arellano, V. M., A. Garcia, R. M. Barragan, G. Izquierdo, A. Aragon and D. Nieva (2003). "An updated conceptual model of the Los Humeros geothermal reservoir (Mexico)." Journal of Volcanology and Geothermal Research 124(1-2): 67-88.

Barker, J. A. (1988). "A generalized radial flow model for hydraulic tests in fractured rock." Water Resources Research 24(10): 1796-1804.

Barthes, V. and C. Mennechet (1984). Prospection géothermique de la région de Bouillante Vieux habitants (Guadeloupe). Etude gravimétrique. 1984, BRGM report N84 SGN 063 GTH.

Batini, F., A. Brogi, A. Lazzarotto, D. Liotta and E. Pandeli (2003). "Geological features of Larderello-Travale and Mt. Amiata geothermal areas (southern Tuscany, Italy); Geology of Italy." Episodes 26(3): 239-244.

Bernard, M.-L., J. Molinié, R.-H. Petit, F. Beauducel, G. Hammouya and G. Marion (2006). "Remote and in situ plume measurements of acid gas release from La Soufrière volcano, Guadeloupe." Journal of Volcanology and Geothermal Research 150(4): 395.

Bertini, G., M. Casini, G. Gianelli and E. Pandeli (2006). "Geological structure of a longliving geothermal system, Larderello, Italy." Terra Nova 18(3): 163-169.

Bodvarsson, G. S., S. M. Benson, O. Sigurdsson, V. Stefansson and E. T. Eliasson (1984). "The Krafla geothermal field, Iceland; 1, Analysis of well test data." Water Resources Research 20(11): 1515-1530.

Bodvarsson, G. S., K. Pruess, V. Stafansson and E. T. Eliasson (1984a). "The Krafla geothermal field, Iceland; 2, The natural state of the system." Water Resources Research 20(11): 1531-1544. 
Bodvarsson, G. S., K. Pruess, V. Stefansson and E. T. Eliasson (1984b). "The Krafla geothermal field, Iceland; 3, The generating capacity of the field." Water Resources Research 20(11): 1545-1559.

Boudon, G., J. Dagain, M. Semet and D. Westercamp (1982).- Carte géologique du Massif volcanique de la Soufrière. Département de la Guadeloupe, Petites Antilles, Editions du BRGM.

CFG (2001). Champ géothermique de Bouillante. Synthèse lithologique des nouveaux puits BO-5, BO-6 et BO-7 et corrélation entre puits. Orléans, CFG report.

Clemente, W. C. and F. L. Villadolid-Abrigo (1993). "The Bulalo geothermal field, Philippines: reservoir characteristics and response to production." Geothermics 22(5/6): 381-394.

Combarnous, M. A. and S. A. Bories (1975). "Hydrothermal convection in saturated porous media." Advances in Hydroscience 10: 231-307.

Cormy, G., J. Demians d'Archimbaud and J. Surcin (1970). "Prospection géothermique aux Antilles françaises, Guadeloupe et Martinique." Geothermics Special Issue(2): 57-72.

Correia, H., O. Sigurdsson, B. Sanjuan, H. Tulinius and E. Lasne (2000). "Stimulation test of a high-enthalpy geothermal well by cold water injection." Geothermal Resources Council Transactions 24: 129-136.

Demians d'Archimbaud, J. and J.-P. Munier-Jolain (1976). "Les progrès de l'exploration géothermique à Bouillante en Guadeloupe." Eurafrep S.A.: 101-104.

Demians d'Archimbaud, J. and J. Surcin (1976). Recherches géothermiques en Guadeloupe.

Dilsiz, C. (2006). "Conceptual hydrodynamic model of the Pamukkale hydrothermal field, southwestern Turkey, based on hydrochemical and isotopic data." Hydrogeology Journal 14(4): 562.

Dim, J. R., Sakura, Y. Sakura, Fukami, H. Fukami, Miyakoshi and A. Miyakoshi (2002). "Spatial characteristics of groundwater temperature in the Ishikari Lowland, Hokkaido, northern Japan: analytical and numerical applications." Hydrogeology Journal 10(2): 296.

Fabriol, H. (2001). Champ géothermique de Bouillante: synthèse des études géophysiques., BRGM report $\mathrm{N}^{\circ} \mathrm{RP}-50259-\mathrm{FR}$.

Fabriol, H., A. Bitri, B. Bourgeois, N. Debeglia, A. Genter, P. Guennoc, P. Jousset, J. Miehé, J. Y. Roig, I. Thinon, H. Traineau, B. Sanjuan and C. Truffert (2005). Geophysical methods applied to the assessment of the Bouillante geothermal field (Guadeloupe, French West Indies). World Geothermal Congress, WGC 2005, Antalaya, Turkey, 2429/04/05.

Fabriol, R. and G. Ouzounian (1985). Prospection géothermique des zones de Bouillante et de la Soufrière (Guadeloupe). Modèle hydrogéochimique., BRGM report Nº5 SGN 433 GTH.

Feuillet, N., I. Manighetti and P. Tapponnier (2001). "Extension active perpendiculaire a la subduction dans l'arc des petites Antilles (Guadeloupe, Antilles francaises)." Comptes Rendus de l'Academie des Sciences, Serie II. Sciences de la Terre et des Planetes 333(9): 583-590.

Feuillet, N., I. Manighetti and P. Tapponnier (2002). "Arc parallel extension and localization of volcanic complexes in Guadeloupe, Lesser Antilles." Jour. Geophys. Res. 107(B12): 2331-2359.

Flores-Márquez, E., G. Jiménez-Suárez, R. Martínez-Serrano, R. Chávez and D. Pérez (2006). "Study of geothermal water intrusion due to groundwater exploitation in the Puebla Valley aquifer system, Mexico." Hydrogeology Journal 14(7): 1216. 
Gadiala, A. and D. Westercamp (1984). Prospection géothermique de la région de Bouillante - Vieux habitants (Guadeloupe). Rapport géologique, BRGM report N84 SGN 063 GTH.

Gandino, A., M. Guidi, C. Merlo, L. Mete, R. Rossi and L. Zan (1985). "Preliminary model of the Ribeira Grande geothermal field (Azores Islands)." Geothermics 14(1): 91-105.

Genter, A. and H. Traineau (2004). Synthèse méthodologique sur l'exploration géothermique haute énergie dans les DOM: approche géologique. Projet GHEDOM, BRGM report BRGM/RP-53130-FR: 86.

Guillou-Frottier, L. (2003). Compilation et analyse des données thermiques sur le champ géothermique de Bouillante. Premières interprétations pour le fonctionnemen du champ géothermique., BRGM Report $\mathrm{N}^{\circ} \mathrm{BRGM} / \mathrm{RP}-52452-\mathrm{FR}$.

Guisseau, D., P. Patrier Mas, D. Beaufort, J. P. Girard, A. Inoue, B. Sanjuan, S. Petit, A. Lens and A. Genter (2007). "Significance of the depth-related transition montmorillonitebeidellite in the Bouillante geothermal field (Guadeloupe, Lesser Antilles)." American Mineralogist 92(11-12): 1800-1813.

Hulen, J. B. and T. D. Anderson (1998). The Awibengkok, Indonesia, geothermal research project. Twenty-Third Workshop on Geothermal Reservoir Engineering, Stanford University, Stanford, California.

Ingebritsen, S. and M. Scholl (1993). "The hydrogeology of Kilauea volcano." Geothermics 22: 255-270.

Kühn, M. and H. Stöfen (2005). "A reactive flow model of the geothermal reservoir Waiwera, New Zealand." Hydrogeology Journal 13(4): 606.

Lachassagne, P., B. Blavoux and M. Livet (2006). Chapitre: I. Généralités sur les eaux souterraines. 5. Aquifères volcaniques. Aquifères et Eaux Souterraines en France. J. C. Roux. Orléans, BRGM Editions. 1: 52-58.

Lachassagne, P. and J. Maréchal (2004). Synthèse des connaissances hydrogéologiques, profondes et de subsurface, sur le champ géothermique de Bouillante. Montpellier, BRGM report $\mathrm{N}^{\circ} \mathrm{RP}-53404-\mathrm{FR}$.

Maréchal, J.-C., P. Perrochet and L. Tacher (1999). "Long term simulation of thermal and hydraulic characteristics in a mountain massif: the Mont-Blanc case study, French and Italien Alps." Hydrogeology Journal 7: 341-354.

Mas, A., D. Guisseau, P. Patrier Mas, D. Beaufort, A. Genter, B. Sanjuan and J. P. Girard (2006). "Clay minerals related to the hydrothermal activity of the Bouillante geothermal field (Guadeloupe)." Journal of Volcanology and Geothermal Research 158(3-4): 380.

Patrier, P., D. Beaufort, A. Mas and H. Traineau (2003). "Surficial clay assemblage associated with the hydrothermal activity of Bouillante (Guadeloupe, French West Indies)." Journal of Volcanology and Geothermal Research 126(1-2): 143.

Sanjuan, B. (2001). Champ géothermique de Bouillante (Guadeloupe): synthèse des travaux réalisés en géochimie avant 1999, BRGM report $\mathrm{N}^{\circ} \mathrm{RC}-51672-\mathrm{FR}, 64 \mathrm{p}$..

Sanjuan, B. and M. Brach (1997). Etude hydrogéochimique du champ géothermique de Bouillante (Guadeloupe), BRGM report NR39880.

Sanjuan, B., E. Lasne and M. Brach (2000). Bouillante geothermal field (Guadeloupe). Geochemical monitoring during a thermal stimulation operation. 25th Workshop on Geothermal Reservoir Engineering, Stanford.

Sanjuan, B., E. Lasne and M. Brach (2001). Bouillante geothermal fluid: mixing and water/rock interaction processes at $250^{\circ} \mathrm{C}$. Proceedings, $10^{\text {th }}$ Water-Rock Interaction (WRI-10), Cagliari, Italy, June 10-15, 911-914. 
Sanjuan, B., Y-M. Le Nindre, A. Menjoz, A. Sbai, M. Brach and E. Lasne (2004). Travaux de recherche liés au développement du champ géothermique de Bouillante. Orléans, BRGM Report NRP-53136-FR: 166 p..

Sanjuan, B., H. Traineau, J. Y. Roig, J. Miehé, C. Cotiche, P. Lachassagne, J. Maréchal, H. Fabriol and M. Brach (2005). Reconnaissance du potentiel géothermique du secteur nord de la baie de Bouillante, en Guadeloupe, par des méthodes d'exploration de surface, BRGM report RC-53634-FR: 120 p..

Smith, D. v. G. S., Bruce D; Blome, Charles D; Pierce,Herbert A; Lambert, Rebecca B (2001). Cretaceous volcanic intrusives in the Edwards Aquifer, Texas asidentified from a high-resolution aeromagnetic survey. Geological Society of America, 2001 annual meeting, Geological Society of America (GSA), Boulder, CO, United States(USA).

Tamanyu, S. and C. P. Wood (2003). "Characterization of geothermal systems in volcanotectonic depressions; Japan and New Zealand." Chishitsu Chousa Kenkyuu Houkoku = Bulletin of the Geological Survey of Japan 54(3-4): 117-129.

Thinon, I., A. Bitri and P. Guennoc (2004). Levé sismique et magnétique le long de la côte ouest de l'île de Basse Terre, Guadeloupe. Apports à la compréhension du contexte structural du champ géothermique de Bouillante. Orléans, BRGM report NRP-53152FR.

Traineau, H. (2001). Champ géothermique de Bouillante (Guadeloupe): Synthèse des travaux réalisés en géologie avant 1999, CFG report.

Traineau, H., B. Sanjuan, D. Beaufort, B. M., C. Castaing, H. Correia, A. Genter and B. Herbrich (1997). The Bouillante geothermal field revisited: new data on the fractured geothermal reservoir in light of a future stimulation experiment in a low productive well. 22nd Workshop Geothermal Reservoir Engineering, Stanford.

Violette, S., E. Ledoux, P. Goblet and J.-P. Carbonnel (1997). "Hydrologic and thermal modeling of an active volcano; the Piton de la Fournaise, Reunion." Journal of Hydrology 191(1-4): 37-63.

Vosteen, H.-D. and R. Schellschmidt (2003). "Influence of temperature on thermal conductivity, thermal capacity and thermal diffusivity for different types of rock; Heat flow and the structure of the lithosphere." Physics and Chemistry of the Earth 28(911): 499-509.

Westercamp, D. and H. Traineau (1987). " Hydrogeologic and geothermal scheme of an insular arc stratovolcano; Mount Pelee, Martinique, French Antilles." Bulletin de la Societe Geologique de France 3(6): 1063-1073. 


\section{Figures}

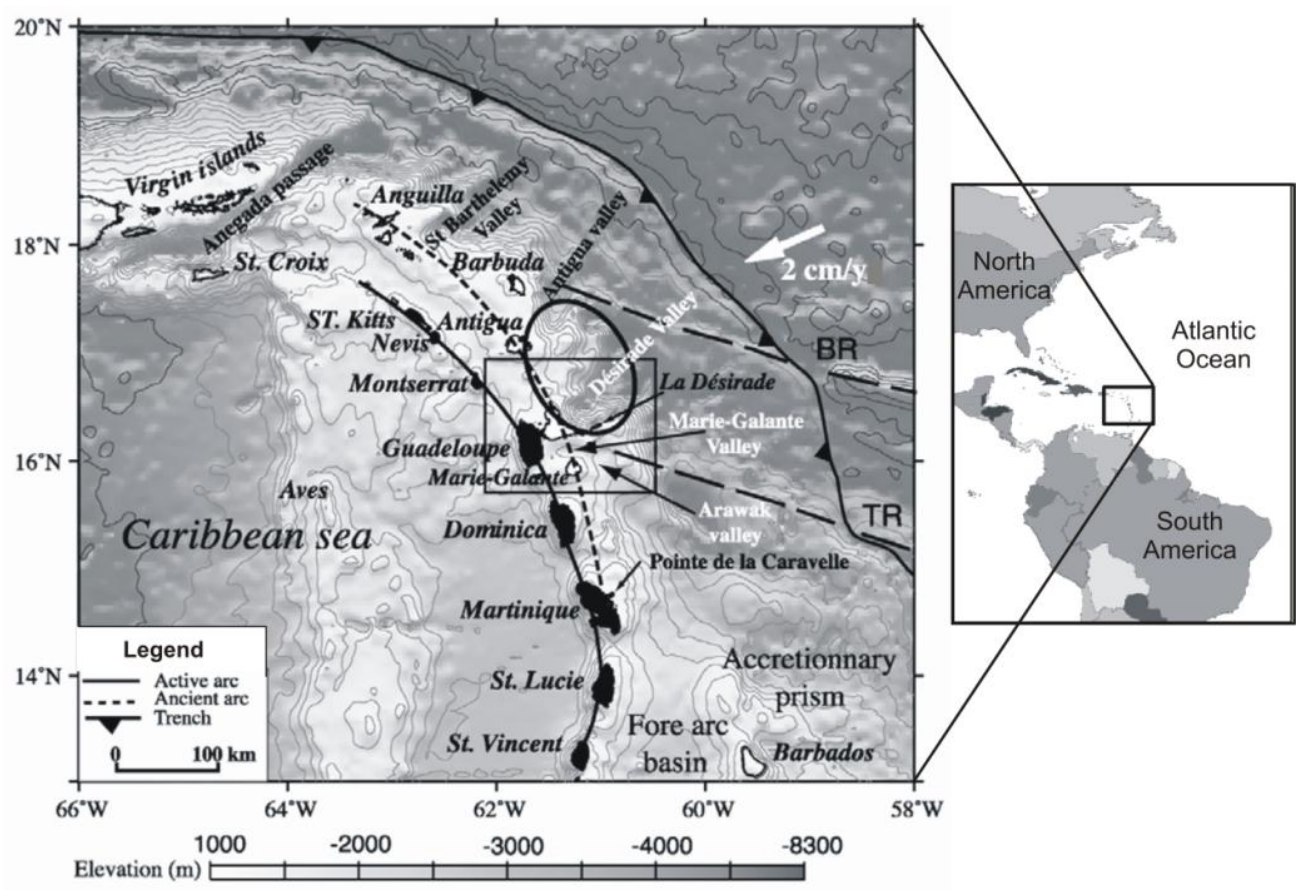

Figure 1: Bathymetric map of the Lesser Antilles arc. Bathymetry from Smith and Sandwell (1997), contour interval $500 \mathrm{~m}$. Continuous black line: recent volcanic arc; dotted black line: ancient arc from Bouysse et al. (1988). Volcanic islands (on recent arc) in black; coral-reef islands (on ancient arc) in white. Black dashed lines mark the Barracuda (BR) and Tiburon ridges (TR) (from Feuillet et al. (2001).

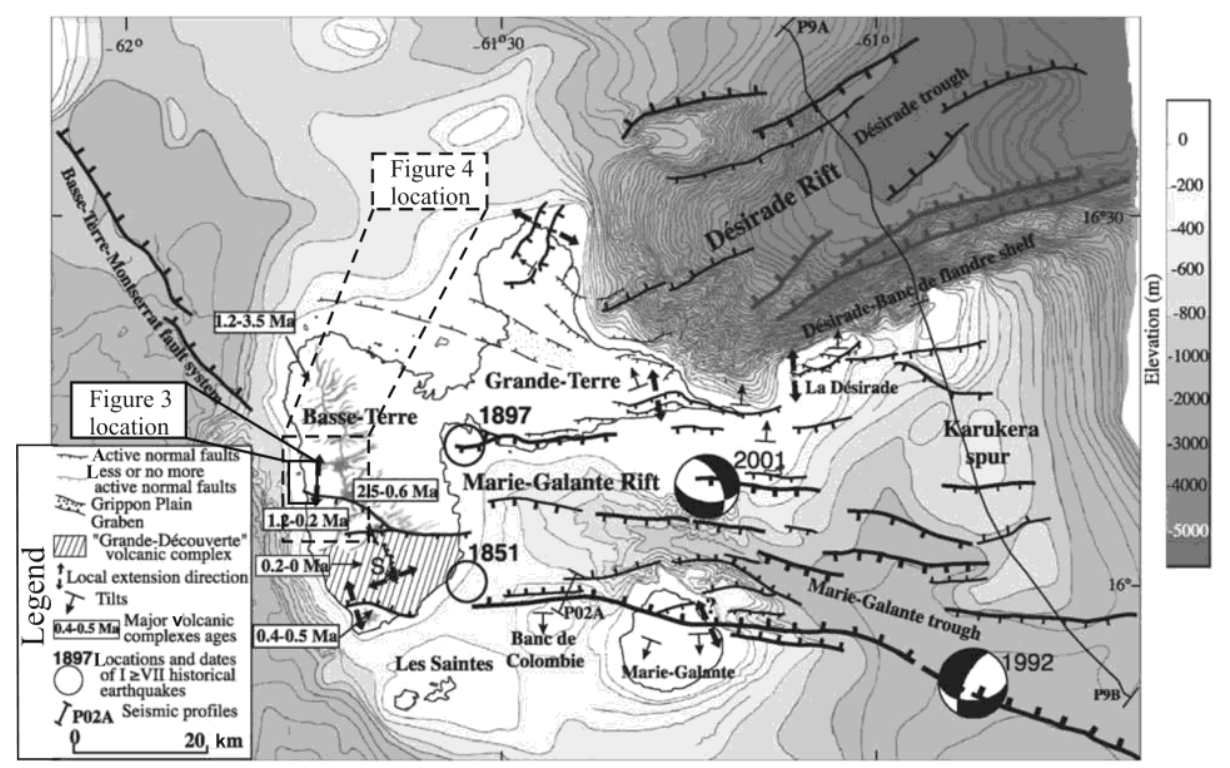

Figure 2: Bathymetric and tectonic map of the Guadeloupe archipelago, modified after Feuillet et al. (2002). Hatched area $=$ recent volcanism $(<0.2 \mathrm{Ma}) ; \mathrm{S}=$ Soufrière; double black arrows indicate local extension direction estimated from microtectonic measurements and fault geometry (see also Fig. 5 located in the general context). 


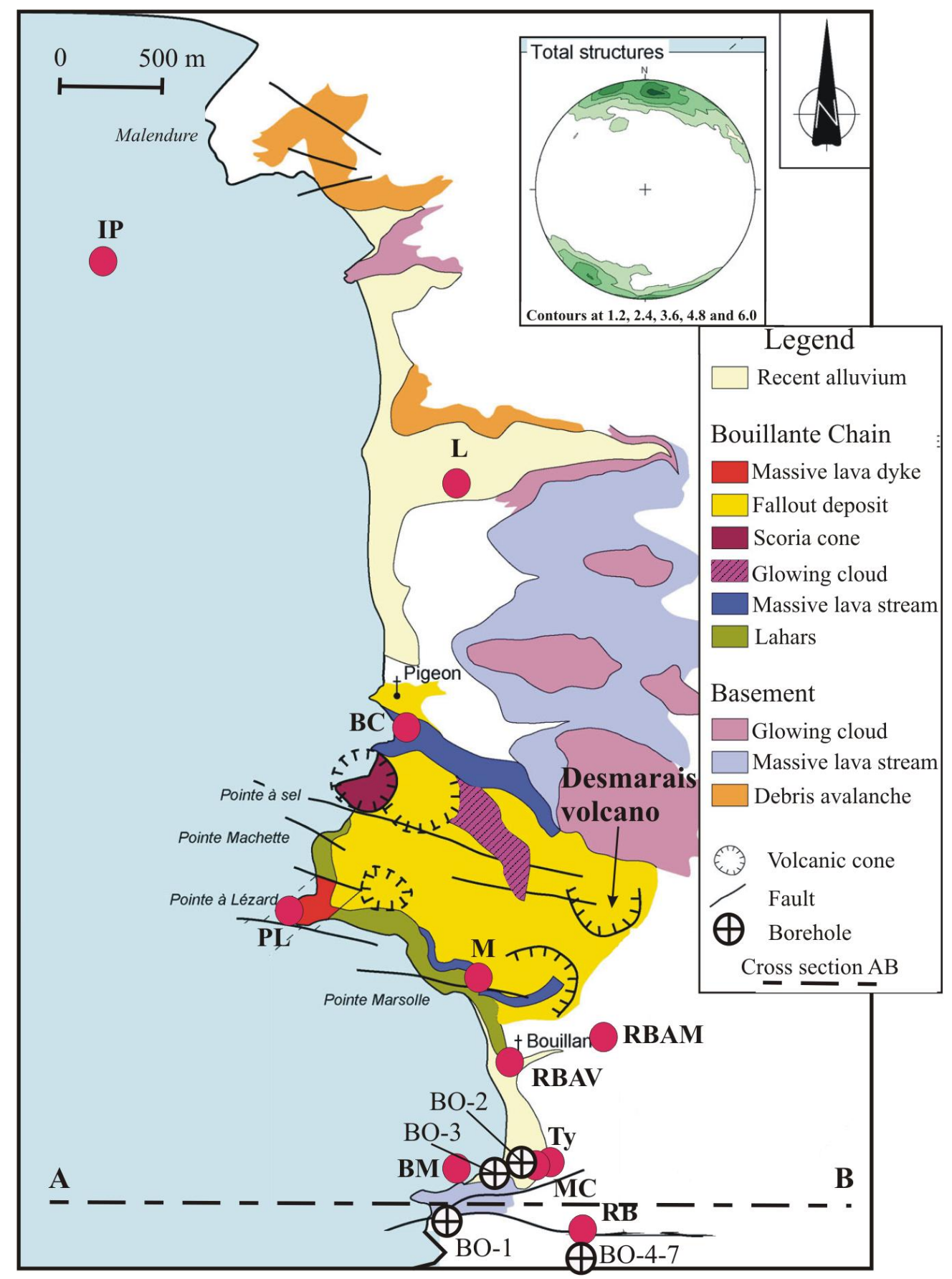

Figure 3: Geological map of the Bouillante site, after Sanjuan et al. (2005) (main hot springs as red dots - see Fig. 5 for the exhaustive location of the springs cited in table 1 -, cross section of figure 6). Up right angle: polar projection diagram of tectonic discontinuities (joints, faults, etc.) from all surface field observations (density representation). 


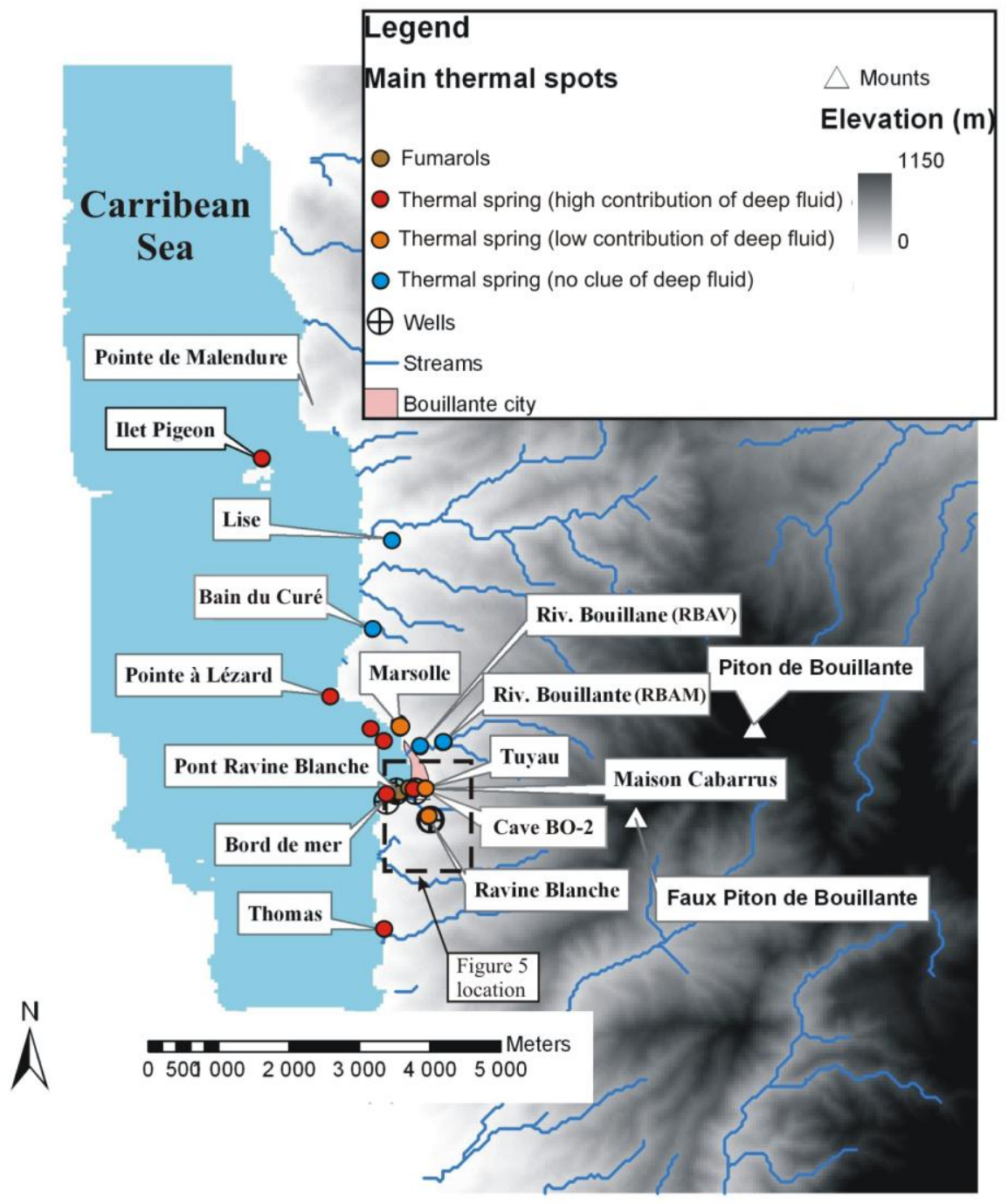

Figure 4: Location of Bouillante on the western coast of Basse Terre Island showing the location of the main thermal spots. The thermal power plant is located in Bouillante town, close to the Tuyau hot spring. The two points "Ravine Renoir" cited in Table 1 are out of this map. 


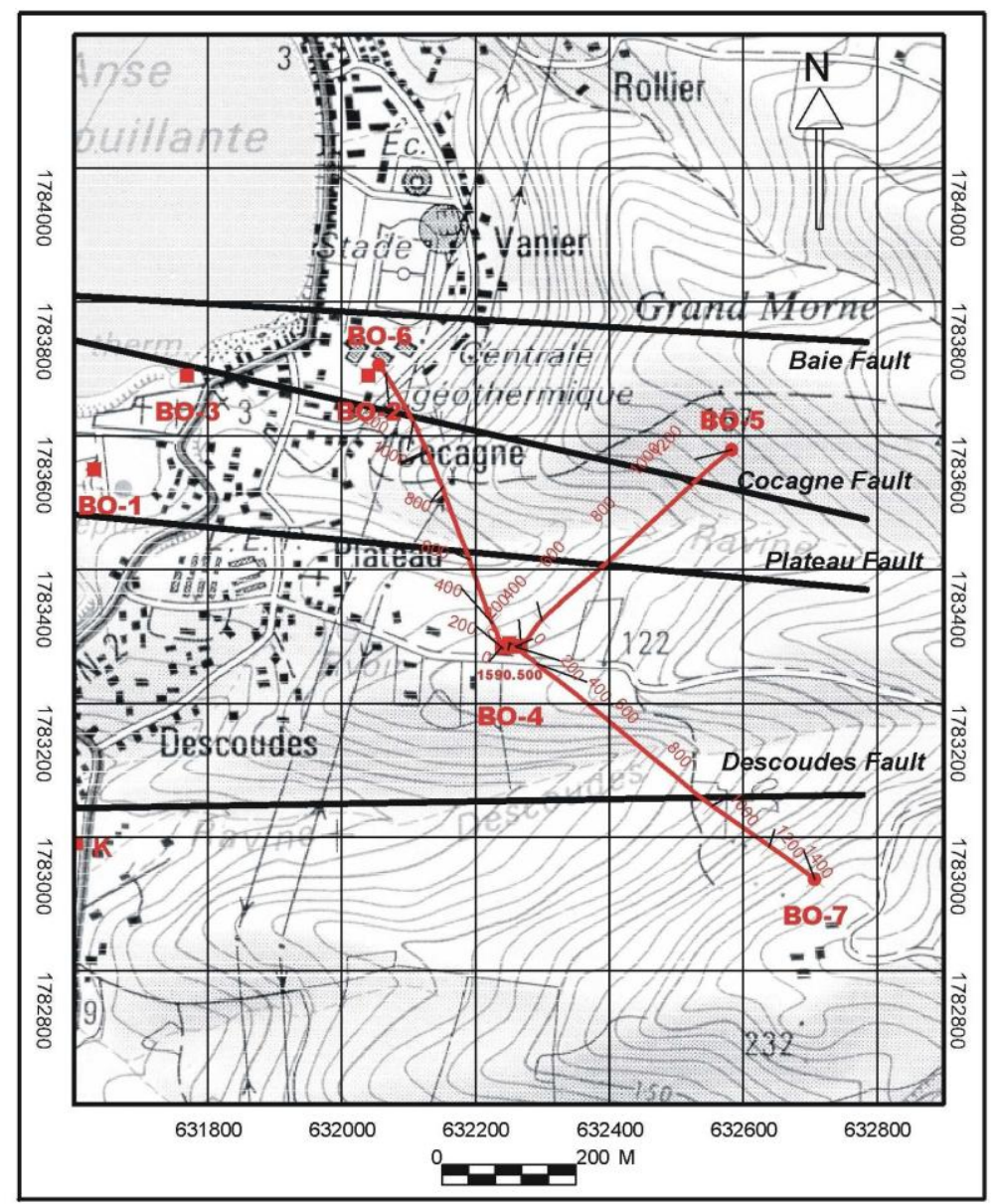

Figure 5: Location map of wells (BO-1 to BO-7) and the main faults. The projection of the non-vertical wells on an horizontal plane is figured, with depths (m).

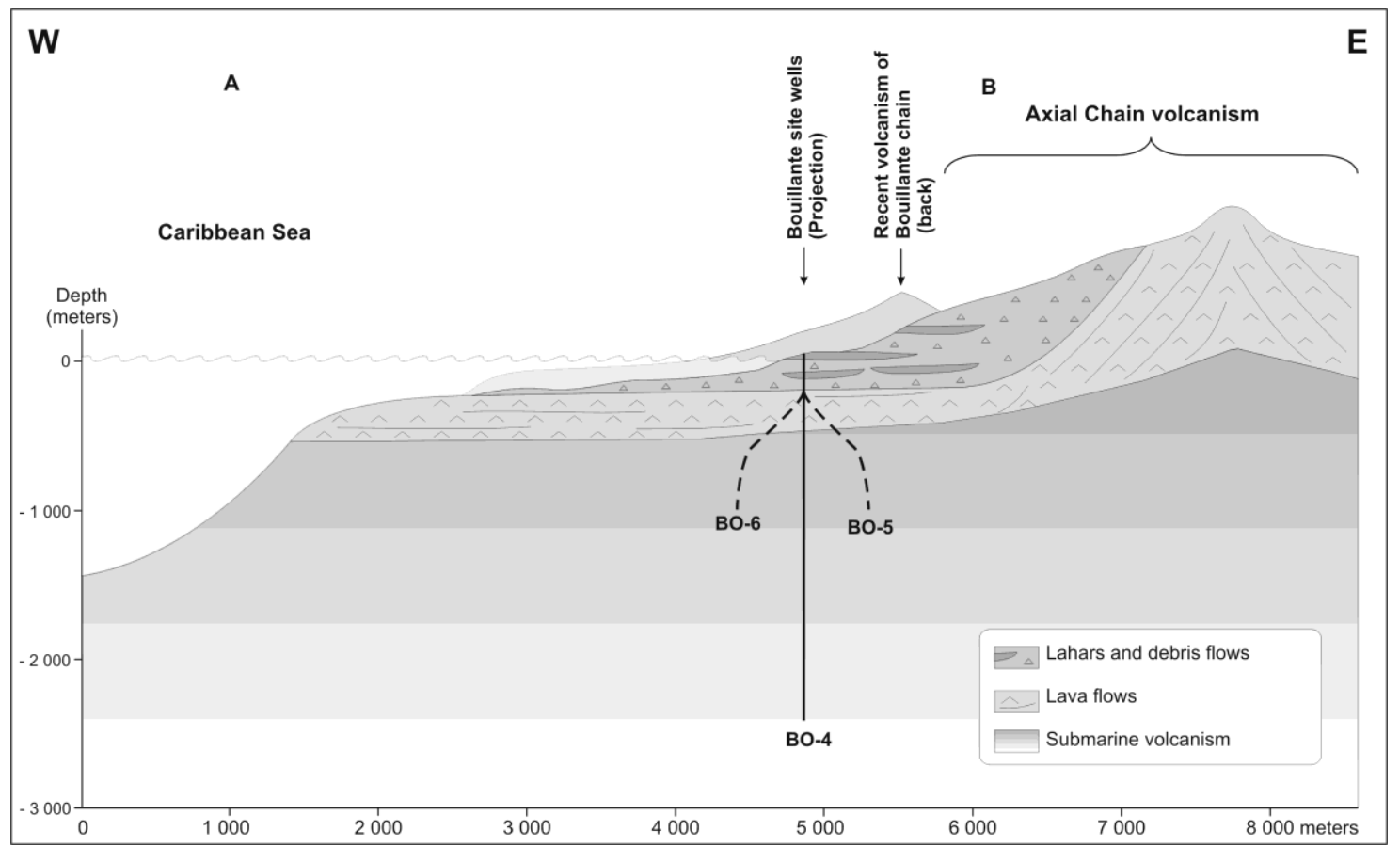

Figure 6: Schematic geological cross section oriented W-E (for location, see Figure 3). 


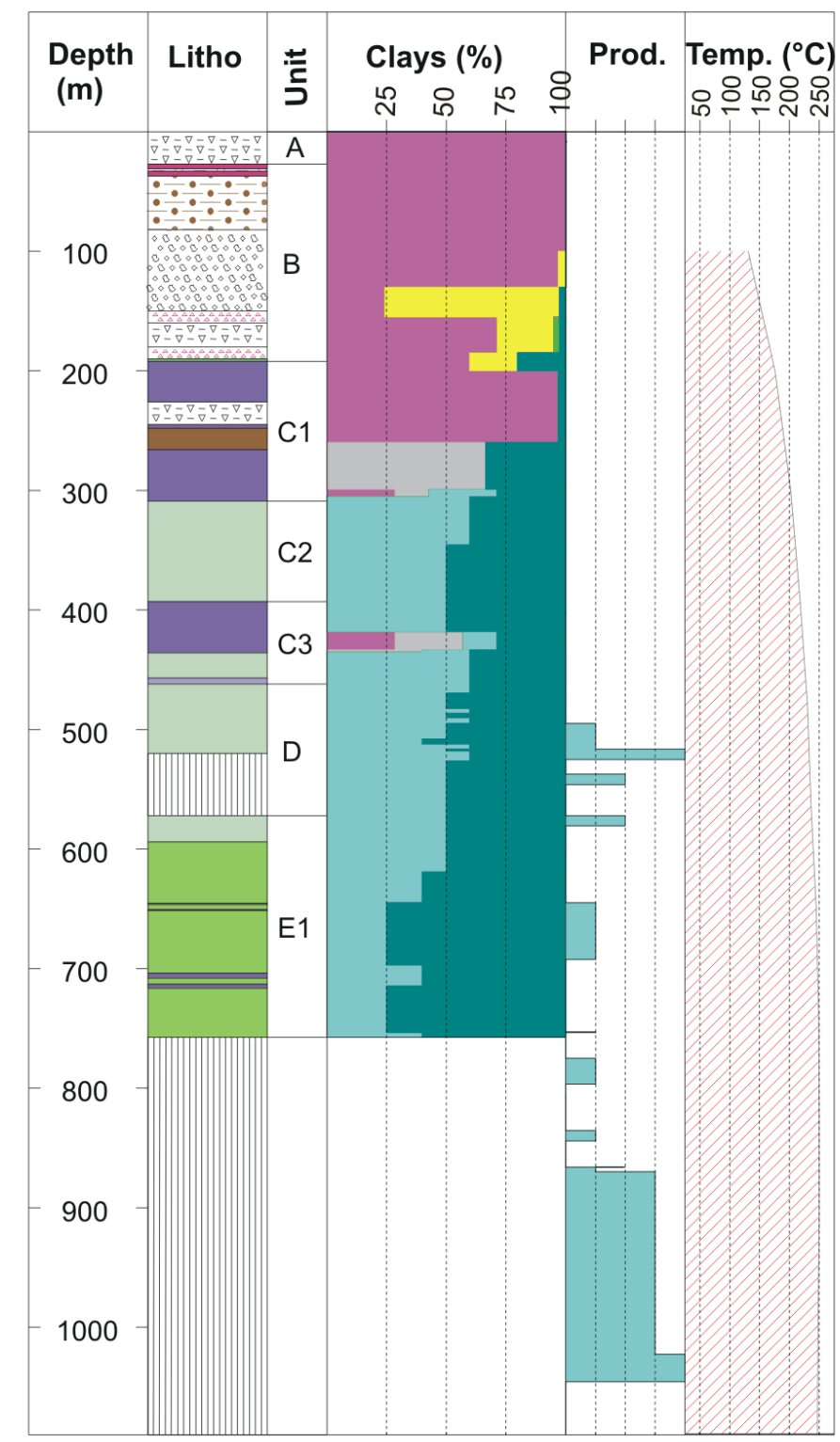

Legend

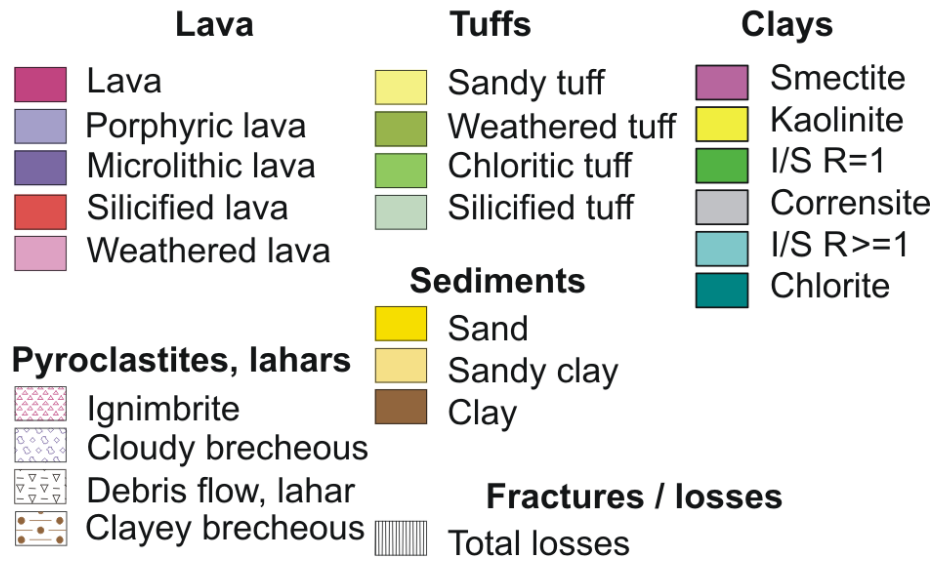

Figure 7: Example of the main data obtained from the well BO-5 (from Sanjuan et al., 2004). The productivity scale is relative, based on mud losses observed during drilling (left: no mud loss; right: total mud loss; in between: partial mud losses). 


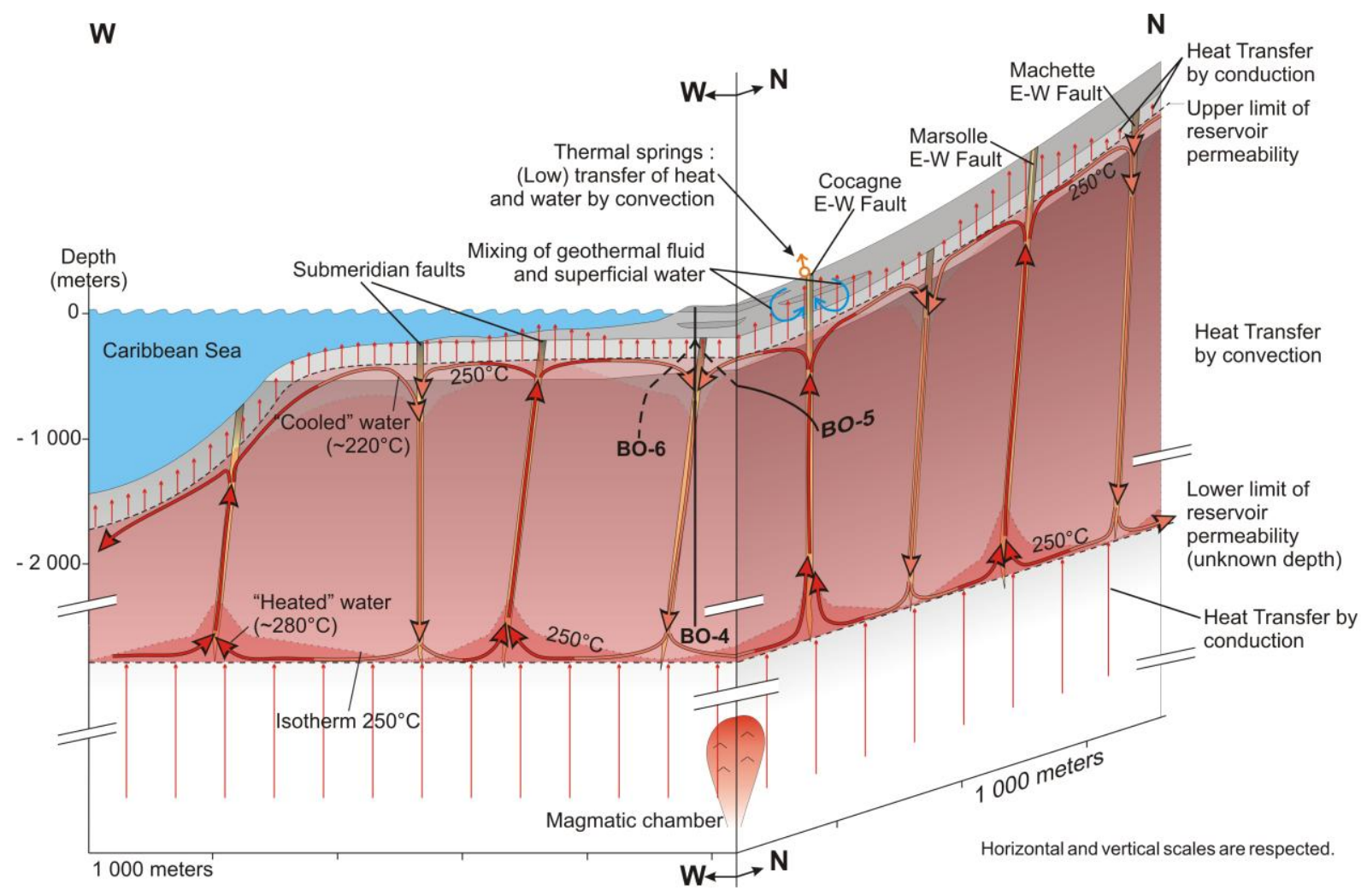

Figure 8: Conceptual model of thermal and water-flow exchanges in the Bouillante geothermal field (note that the size of the magmatic chamber is not at scale; it should probably be enlarged).
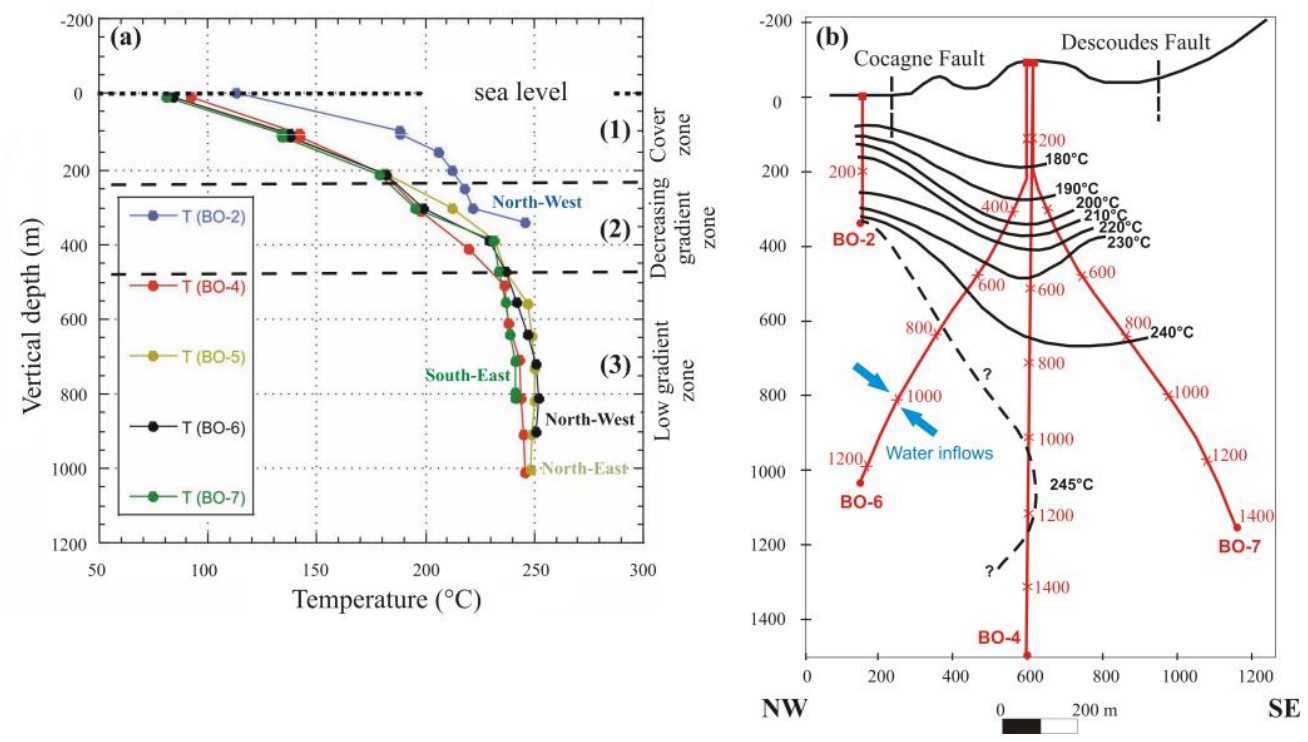

Figure 9: Equilibrium temperature-depth profiles in the main Bouillante boreholes (left) and isotherms in a NW-SE plane (right), (from Guillou-Frottier, 2003) 


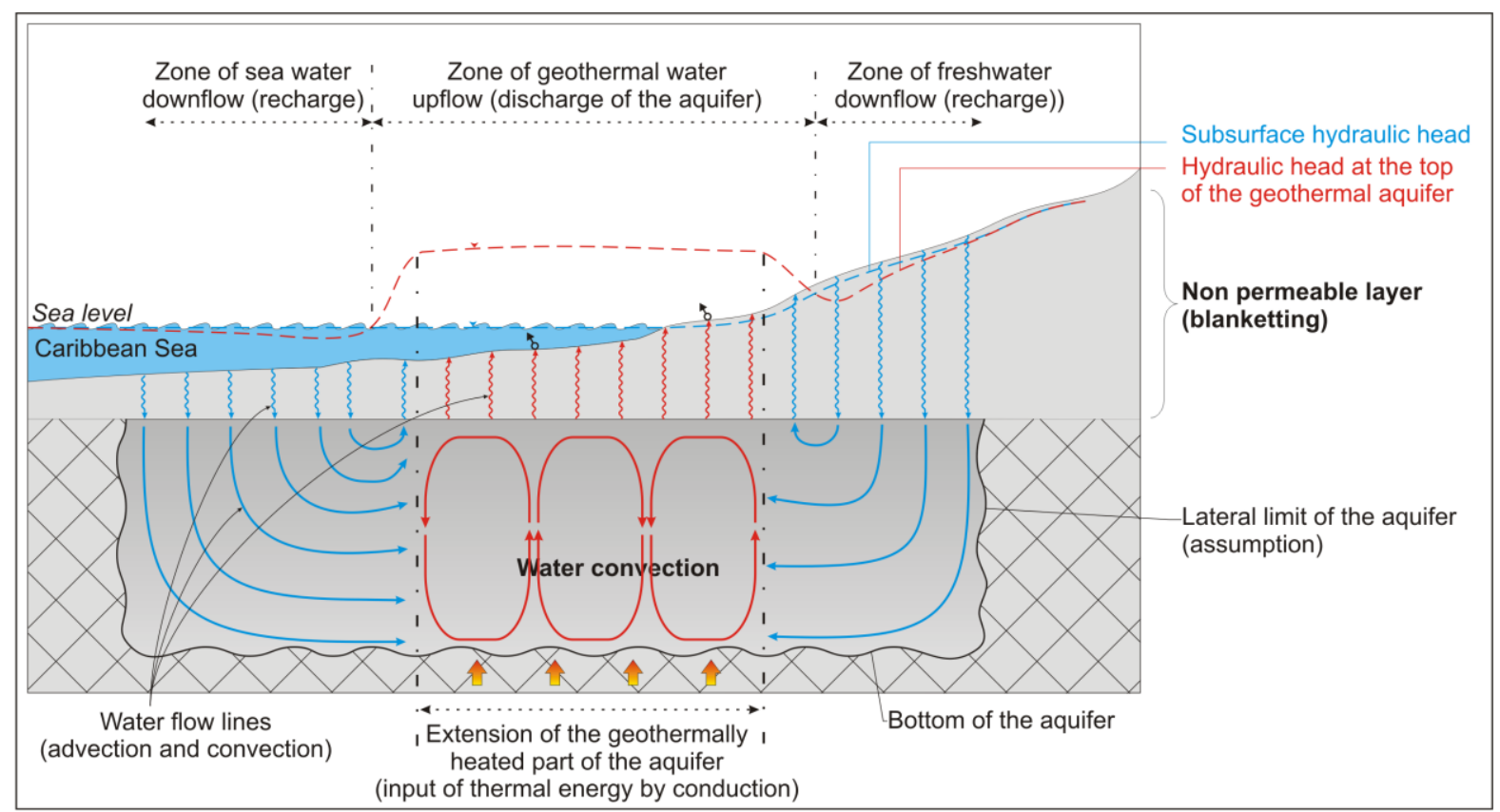

Figure 10: Schematic distribution of the hydraulic heads, water flow lines, and main areas of discharge and recharge of the Bouillante geothermal aquifer (not to scale) in natural conditions (without artificial discharge)

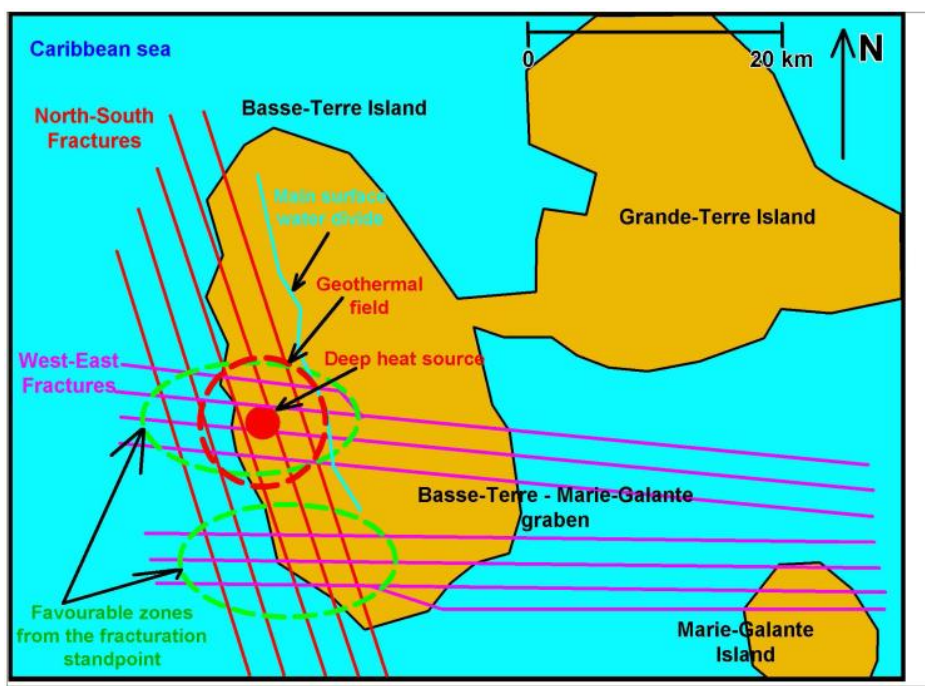

Figure 11: Schematic conceptual model explaining, at the Basse-Terre island scale, the origin and location of the geothermal field. 